\title{
Sediment history mirrors Pleistocene aridification in the Gobi Desert (Ejina Basin, NW China)
}

\author{
Georg Schwamborn ${ }^{1,2,3}$, Kai Hartmann ${ }^{1}$, Bernd Wünnemann ${ }^{1,4}$, Wolfgang Rösler ${ }^{5}$, Annette Wefer-Roehl ${ }^{6}$, \\ Jörg Pross $^{7}$, Marlen Schlöffel ${ }^{8}$, Franziska Kobe $^{9}$, Pavel E. Tarasov ${ }^{9}$, Melissa A. Berke ${ }^{10}$, and Bernhard Diekmann ${ }^{2}$ \\ ${ }^{1}$ Freie Universität Berlin, Applied Physical Geography, 12249 Berlin, Germany \\ ${ }^{2}$ Alfred Wegener Institute, Helmholtz Centre for Polar and Marine Research, 14473 Potsdam, Germany \\ ${ }^{3}$ Eurasia Institute of Earth Sciences, Istanbul Technical University, Maslak 34469, Istanbul, Turkey \\ ${ }^{4}$ East China Normal University, State Key Laboratory of Estuarine and Coastal Research, Shanghai 200241, China \\ ${ }^{5}$ Department of Geosciences, University of Tübingen, 72074 Tübingen, Germany \\ ${ }^{6}$ Senckenberg Gesellschaft für Naturforschung, 60325 Frankfurt, Germany \\ ${ }^{7}$ Institute of Earth Sciences, Heidelberg University, 69120 Heidelberg, Germany \\ ${ }^{8}$ Institute of Geography, University of Osnabrück, 49074 Osnabrück, Germany \\ ${ }^{9}$ Institute of Geological Sciences, Freie Universität Berlin, 12249 Berlin, Germany \\ ${ }^{10}$ University of Notre Dame, Department of Civil and Environmental Engineering and Earth Sciences, \\ Notre Dame, IN 46556, USA
}

Correspondence: Georg Schwamborn (georg.schwamborn@fu-berlin.de)

Received: 22 October 2019 - Discussion started: 4 November 2019

Revised: 28 February 2020 - Accepted: 18 March 2020 - Published: 23 July 2020

\begin{abstract}
Central Asia is a large-scale source of dust transport, but it also held a prominent changing hydrological system during the Quaternary. A $223 \mathrm{~m}$ long sediment core (GN200) was recovered from the Ejina Basin (synonymously Gaxun Nur Basin) in NW China to reconstruct the main modes of water availability in the area during the Quaternary. The core was drilled from the Heihe alluvial fan, one of the world's largest alluvial fans, which covers a part of the Gobi Desert. Grain-size distributions supported by endmember modelling analyses, geochemical-mineralogical compositions (based on XRF and XRD measurements), and bioindicator data (ostracods, gastropods, pollen and non-pollen palynomorphs, and $n$-alkanes with leaf-wax $\delta \mathrm{D}$ ) are used to infer the main transport processes and related environmental changes during the Pleistocene. Magnetostratigraphy supported by radionuclide dating provides the age model. Grainsize endmembers indicate that lake, playa (sheetflood), fluvial, and aeolian dynamics are the major factors influencing sedimentation in the Ejina Basin. Core GN200 reached the pre-Quaternary quartz- and plagioclase-rich "Red Clay" formation and reworked material derived from it in the core bottom. This part is overlain by silt-dominated sediments be-
\end{abstract}

tween 217 and $110 \mathrm{~m}$ core depth, which represent a period of lacustrine and playa-lacustrine sedimentation that presumably formed within an endorheic basin. The upper core half between 110 and $0 \mathrm{~m}$ is composed of mainly silty to sandy sediments derived from the Heihe that have accumulated in a giant sediment fan until modern time. Apart from the transition from a siltier to a sandier environment with frequent switches between sediment types upcore, the clay mineral fraction is indicative of different environments. Mixed-layer clay minerals (chlorite/smectite) are increased in the basal Red Clay and reworked sediments, smectite is indicative of lacustrine-playa deposits, and increased chlorite content is characteristic of the Heihe river deposits. The sediment succession in core GN200 based on the detrital proxy interpretation demonstrates that lake-playa sedimentation in the Ejina Basin has been disrupted likely due to tectonic events in the southern part of the catchment around $1 \mathrm{Ma}$. At this time Heihe broke through from the Hexi Corridor through the Heli Shan ridge into the northern Ejina Basin. This initiated the alluvial fan progradation into the Ejina Basin. Presently the sediment bulge repels the diminishing lacustrine environment further north. In this sense, the uplift of the hin- 
terland served as a tipping element that triggered landscape transformation in the northern Tibetan foreland (i.e. the Hexi Corridor) and further on in the adjacent northern intracontinental Ejina Basin. The onset of alluvial fan formation coincides with increased sedimentation rates on the Chinese Loess Plateau, suggesting that the Heihe alluvial fan may have served as a prominent upwind sediment source for it.

\section{Introduction}

The aridification of the Asian interior since $\sim 2.95-2.5 \mathrm{Ma}$ (Su et al., 2019) is one of the major palaeoenvironmental events during the Cenozoic. The "Red Clay" formation and loess deposits on the Chinese Loess Plateau, which are products of the Asian aridification, have been used to broadly constrain the drying history of the Asian interior during the Neogene (Porter, 2007). Studies on these sediment sequences indicate that aeolian deposits started to accumulate on the Chinese Loess Plateau since $~ 7-8 \mathrm{Ma}$ (Song et al., 2007), suggesting an initiation of Asian aridification during the late Miocene. Cenozoic uplift of the Tibetan Plateau had a profound effect upon the desertification in the Asian interior by enhancing it (Guo et al., 2002). The timing of the uplift of the northern Tibetan Plateau has been under debate for decades and is still so today, i.e. the onset of intensive exhumation in the Qilian Shan at the northeastern border of the Tibetan Plateau is thought to occur at $\sim 18-11 \mathrm{Ma}$ and at approximately $7 \pm 2 \mathrm{Ma}$ (Pang et al., 2019). Wang et al. (2017) suggest an emergence of the Qilian Shan during the late Miocene, the area where the Heihe (synonymously Hei River) evolves from its upper reaches on the northern flanks.

River sediments from the Heihe and the more southeasterly flowing Shiyang River are considered a major source for the Badain Jaran Desert and Tengger Desert (Yang et al., 2012; Li et al., 2014; Wang et al., 2015; Hu and Yang, 2016). It has been argued that they belong to the dust sources for the Chinese Loess Plateau (Derbyshire et al., 1998; Sun, 2002; Che and Li, 2013; Pan et al., 2016; Yu et al., 2016). Today, the Heihe flows from the Hexi Corridor through the Heli Shan northwards into the Ejina Basin (synonymously Gaxun Nur Basin), where it forms a giant alluvial fan (Fig. 1). When arriving at the lower reaches of the Heihe, the river carries not only the sediments eroded from the Qilian Shan but also sediments washed from the western Beishan by ephemeral streams and silty sands blown in from Mongolia in the north (Li et al., 2011; Che and Li, 2013). In addition, ephemeral channels originating from the eastern Altay Mountains (synonymously Altai Mountains) indicate that large amounts of sediments are transported from there to the Ejina Basin. During the local wet periods of marine isotope stages (MIS) 3 and 5, and the mid-Holocene (Yang et al., 2010, 2011),

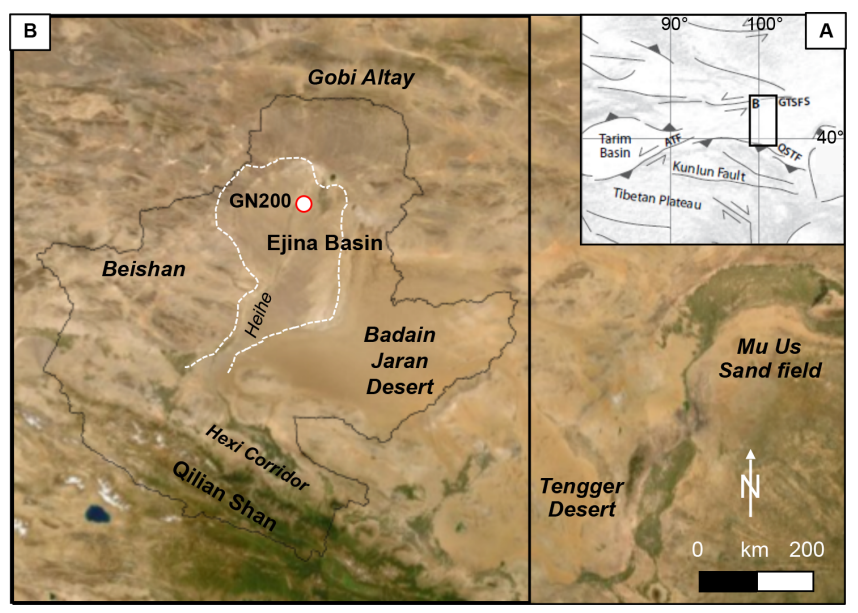

Figure 1. (a) The study site is located in an area dominated by left-lateral transpression due to the ongoing India-Eurasia collision. GTSFS = Gobi Tien Shan fault system, QSTF = Qilian Shan thrust front, ATF = Altyn Tagh fault. (b) White dotted line: Heihe fan covering much of the Ejina Basin. Black line: Heihe catchment. GN200 marks the coring site. (Service layer credits: Esri, DigitalGlobe, GeoEye, Earthstar Geographics, CNES/Airbus DS, USDA, USGS, AeroGRID, IGN, and the GIS User Community. The map was created using ArcGIS ${ }^{\circledR}$ software. ArcGIS ${ }^{\circledR}$ is the intellectual property of Esri and is used herein under licence. (OEsri.)

strong fluvial input from the Altay Mountains can be expected (Wünnemann et al., 2007a).

The Ejina Basin has a lateral and vertical set of different sediment archives, i.e. lacustrine, playa-lacustrine, aeolian, and fluvial-alluvial (Wünnemann and Hartmann, 2002; Zhu et al., 2015; Yu et al., 2016). Coring the alluvial fan and underlying deposits at a central position within the basin is thus expected to yield a record that constrains the timing and mirrors the complex interactions between (i) Quaternary climate forcing of the Heihe discharge, (ii) a tectonic triggering of sediment pulses from the uplifting Qilian Shan, and (iii) internal sedimentation dynamics as they are characteristic of downstream alluvial fan progradation.

The purpose of this study is to reconstruct the palaeoenvironmental change driven by climate and tectonic history in the area based on a sediment core from a distal position of the Heihe alluvial fan. The sediment is used for generating sedimentological data (i.e. grain size, XRF, XRD) that are augmented by information from selected bioindicators (ostracod and gastropod counts, pollen and non-pollen palynomorphs, $n$-alkane abundances, and $\delta \mathrm{D}$ values). Based on this multiproxy dataset, the transition from more humid to more arid conditions in the Ejina Basin during the past $2.5 \mathrm{Ma}$ years is reconstructed. 


\section{Geographical, tectonic, and climatic setting}

The Ejina Basin is located in the Gobi Desert and part of the Alashan Plateau. It is an intramontane basin bordered by the Heli Shan in the south, the Beishan to the west, the Badain Jaran Desert to the east, and the eastern Altay Mountains to the north (Fig. 1). The Ejina Basin has developed as a pull-apart basin between the northern Tibetan uplands (i.e. the Qilian Shan) in the south and the Gobi Altay-Tien Shan mountain chain in the north (Becken et al., 2007). There is predominantly a left-lateral transpression acting on the regional upper crust due to the ongoing India-Eurasia collision (Cunningham et al., 1996). Allen et al. (2017, and references therein) describe that seismicity with earthquake magnitudes $M>7$ have affected the Qilian Shan and the Hexi Corridor (see Fig. 1) in historic times. Neotectonic activity at the eastern edge of the Ejina Basin was interpreted based on graben geometry detected within crystalline basement using resistivity measurements (Becken et al., 2007; Hölz et al., 2007). Temporal and spatial patterns of fluvial-alluvial and lacustrine deposition are likely influenced by neotectonic movements; e.g. the western basin margin has a subsidence rate of ca. $0.8-1.1 \mathrm{~m} \mathrm{kyr}^{-1}$ (Hartmann et al., 2011), whereas in the northeastern part of the basin the occurrence of seismites illustrates that seismicity has caused sediment rupture in close vicinity to normal fault lines (Rudersdorf et al., 2017). The drilling took place in the centre of the Ejina Basin $\left(42^{\circ} 3^{\prime} 12.96^{\prime \prime} \mathrm{N}, 100^{\circ} 54^{\prime} 14.4^{\prime \prime} \mathrm{E}\right)$ at $936 \mathrm{~m}$ a.s.l. (above sea level) at a distance to known fault lines.

From south to north, the elevation ranges between $1300 \mathrm{~m}$ and $880 \mathrm{~m}$ a.s.l. The Heihe main stream entering the Ejina Basin has a length of more than $900 \mathrm{~km}$ (X. Li et al., 2018) and originates from the slopes of the Qilian Shan in the south. From its upper reaches, it flows through the foreland of the Hexi Corridor and arrives at the lower reaches with two branches that are likely controlled by fault lines. Here, the Heihe builds up one of the world's largest alluvial fan systems in the endorheic Ejina Basin (Hartmann et al., 2011).

The Heihe basin covers an area of approximately $28000 \mathrm{~km}^{2}$, while the total catchment of the Heihe system, connected with glaciers in the Qilian Shan (> 4000 m a.s.l.), comprises roughly $130000 \mathrm{~km}^{2}$. Along the distal part of the basin, three terminal lakes, namely Ejina, Sogo Nur, and Juyanze, form a chain of lakes, which presently are all dried up (Wünnemann et al., 2007a). Radiocarbon dating of ancient shorelines suggests that relative lake-level highstands occurred during MIS 3 (Wünnemann and Hartmann, 2002; Wünnemann et al., 2007b; Hartmann et al., 2011), although the ${ }^{14} \mathrm{C}$-based chronology for the area may underestimate the timing when compared with IRSL OSL (infrared stimulated luminescence optically stimulated luminescence) results (Zhang et al., 2006; Wang et al., 2011; Long and Shen, 2015; Li et al., 2018a, b).

Presently the winter Siberian Anticyclone dominates the climate conditions in the basin (Chen et al., 2008; Mölg et al., 2013). For the seasonal cycle, Liu et al. (2016) have ascertained that there are strong winds, especially in spring and autumn, with maximum wind speeds of $16.5 \mathrm{~m} \mathrm{~s}^{-1}$. Westerly winds prevailing during summer in the area thereby interact with humid air masses of the summer monsoon further south to release occasional heavy rain fall and thunderstorms (Domrös and Peng, 2012), which may occur at least in the Badain Jaran and Tengger deserts (Wünnemann, 1999).

The study area is characterized by a continental climate that is extremely hot in the summer and cold in the winter; the maximum daily temperature is $41^{\circ} \mathrm{C}$ (in July) and the minimum daily temperature is $-36^{\circ} \mathrm{C}$ (in January). According to data from the Ejina weather station between 1959 and 2015, the mean annual temperature, precipitation, relative humidity, and wind speed were $9.0^{\circ} \mathrm{C}, 36.6 \mathrm{~mm}, 33.7 \%$, and $3.3 \mathrm{~m} \mathrm{~s}^{-1}$, respectively, and the mean annual potential evaporation is as high as $3755 \mathrm{~mm}$ (Liu et al., 2016). The growing season in the Ejina Basin is from April to September, during which time it is ice free and has seasonal Heihe river runoff. In contrast, the annual precipitation in the upper reaches in the Qilian Shan reaches 300-500 mm (Wang and Cheng, 1999; Wünnemann et al., 2007a). Today, only the Ejina Oasis near Juyanze palaeolake receives ephemeral water input. Typical geomorphological features in the Ejina Basin are gravel plains, yardangs, playas, sand fields, and sporadically distributed mobile linear and barchan dunes (Zhu et al., 2015; Yu et al., 2016).

Modern vegetation of the Alashan Plateau and the foothills of the Qilian Shan is dominated by semi-desert and desert plant communities, mainly consisting of shrubs, dwarf shrubs, and low herbs (Herzschuh et al., 2004). Limited in space, steppe vegetation is dominated by various dryresistant grasses (e.g. Stipa), shrubs, and forb species. Riparian arboreal vegetation typical for the Heihe banks and former river beds is represented by Populus euphratica, Sophora alopecuroides, and Tamarix ramosissima among the dominant taxa (Herzschuh et al., 2004). Sedge (Carex), grass (Poaceae), and various forb species are typical members of salty meadow and marshy vegetation communities (Hou, 2001).

\section{Methods}

A rotational drilling system has been used for coring with $3 \mathrm{~m}$ long metal tubes $80-120 \mathrm{~mm}$ in diameter. Once a core segment was retrieved, it was pressed out immediately, halved, described, and photographically documented. Subtracting core gaps and overlaps, the length of the core is $223.7 \mathrm{~m}$ with a recovery rate of $96 \%$. On average sampling of 2 to $5 \mathrm{~cm}$ thick slices was done three times per metre or in accordance with sediment change for studying various sediment properties as described below. 


\subsection{Non-destructive analyses}

After core splitting, several non-destructive analyses were carried out including visual description, optical line scanning, magnetic susceptibility analyses, and XRF element scanning. Magnetic susceptibility measurements at $1 \mathrm{~cm}$ resolution were carried out on one core half using a Bartington MS2E sensor, while the other half was scanned with an Avaatech core scanner to semi-quantitatively determine elemental compositions at $1 \mathrm{~cm}$ resolution. We applied a rhodium tube at 150 and $175 \mu \mathrm{A}$ with detector count times of 10 and $15 \mathrm{~s}$ for elemental analysis at $10 \mathrm{kV}$ (no filter) and $30 \mathrm{kV}$ (Pd-thick filter). Element intensities were obtained by post-processing of the XRF spectra using the Canberra WinAxil software with standard software settings and spectrum-fitting models. The element intensities depend on the element concentration but also on matrix effects, physical properties, the sample geometry, and hardware settings of the scanner (Tjallingii et al., 2007). We accepted modelled chi-square values $\left(\chi^{2}\right)<2$ as a parameter of measured peak intensity curve fitting for the relevant elements.

\subsection{Grain-size distribution and endmember modelling analysis}

Sediment grain-size distributions were determined using a laser diffraction grain size analyser (Malvern Mastersizer 3000). Prior to laser sizing, the samples were removed from organic carbon using $\mathrm{H}_{2} \mathrm{O}_{2}$ oxidation on a platform shaker until reaction ceased. The endmember modelling algorithm (EMMA) after Dietze et al. (2012) and modified by Dietze and Dietze (2019) was applied to the grain size data in order to extract meaningful endmember (EM) grain size distributions and to estimate their proportional contribution to the sediments. Results were translated into a core log that illustrates the succession and thickness of EM types. EM modelling analyses are used to address the main sediment types with their associated transport mechanisms.

\subsection{Bulk mineralogy}

The mineralogical composition of freeze-dried and milled samples was analysed by standard X-ray diffractometry (XRD) using an Empyrean PANalytical goniometer by applying $\mathrm{CuK} \alpha$ radiation $(40 \mathrm{kV}, 40 \mathrm{~mA})$ as outlined in Petschick et al. (1996). Samples were scanned from 5 to $65^{\circ} 2 \theta$ in steps of $0.02^{\circ} 2 \theta$, with a counting time of $4 \mathrm{~s}$ per step. The intensity of diffracted radiation was calculated as counts of peak areas using XRD processing software (MacDiff, Petschick, 1999). Mineral inspection focused on quartz, plagioclase and K-feldspar, hornblende, mica, calcite, and dolomite. Accuracy of this semi-quantitative XRD method is estimated to be between 5\%-10\% (Gingele et al., 2001).

\subsection{Clay mineralogy}

The clay fraction $(<2 \mu \mathrm{m})$ was separated using settling times according to the Atterberg procedure. Clay particles were oriented using negative pressure below membrane filters and they were mounted as an oriented aggregate mount on aluminium stubs with the aid of double-sided adhesive tape. The analyses were run from 2.49 to $32.49^{\circ} 2 \theta$ on a PANalytical diffractometer. Two X-ray diffractograms were performed: one from the air-dried sample and one from the sample after ethylene glycol vapour saturation was completed for $12 \mathrm{~h}$. Estimation of clay mineral abundances focused on smectite, mixed-layer smectite / chlorite (10.6 $)$ ), chlorite, and kaolinite (calculated to a sum of $100 \%$ ) and is based on peak intensities. Clay analyses were made only from silt-dominated samples.

\subsection{Fossil counts}

Counts of fossils, i.e. ostracods and gastropods, have been conducted from 62 samples each comprising $40-85 \mathrm{~g}$ of dry weight. The size fractions of $>250,250-125$, and $125-63 \mu \mathrm{m}$ were examined after wet sieving using deionized water. Encountered shells were determined to at least the genus level. Shell fragments were also registered, but results have been excluded from further discussion due to the assumption that the material points to reworking. To yield meaningful numbers, count results have been normalized to $100 \mathrm{~g}$ of dry weight.

\subsection{Pollen analysis and biome reconstruction}

For pollen analysis, a total of 62 samples (each representing a $2 \mathrm{~cm}$ thick layer) was taken from the layers of clayey silt within the $217.2-113 \mathrm{~m}$ depth interval with a higher potential for sufficiently good pollen preservation. The samples containing 3 to $5 \mathrm{~g}$ of sediment were then treated in the pollen laboratory at the Institute of Geological Sciences (FU Berlin) using the dense media separation method as described in Leipe et al. (2019). The laboratory protocol includes successive treatment of sediment sample with $10 \% \mathrm{HCl}, 10 \% \mathrm{KOH}$, dense media separation using sodium polytungstate (SPT with a density of $2.1 \mathrm{~g} \mathrm{~cm}^{-3}$ ), and acetolysis. In order to estimate pollen concentration (grains per gram), one tablet with a known quantity of exotic $\mathrm{Ly}$ copodium clavatum marker spores (Batchnr. 483216) was added to each sample prior to the chemical treatment following Stockmarr (1971). At least 200 terrestrial pollen grains were counted in the samples with a concentration of more than 500 pollen grains per gram and a moderate to good pollen preservation. The percentages of terrestrial pollen taxa refer to the total pollen sum taken as $100 \%$. The percentages of fern spores, aquatic plants, and algae refer to the sum of all pollen and spores. Tilia version 1.7.16 software (Grimm, 
2011) was used for calculating individual taxa percentages and drawing the diagram.

Interpretation of pollen records from desert regions is challenging due to several limiting factors, including partially poor pollen preservation, long-distance transport of pollen (e.g. pollen from coniferous and birch trees from mountain forests), and redeposition of pollen from eroded older sediments (Gunin et al., 1999). Modern surface pollen spectra greatly facilitate the interpretation of fossil records from the arid regions (Tarasov et al., 1998). In this study, we used a published set of 55 recent pollen spectra from the Alashan Plateau and Tsilian Shan (Herzschuh et al., 2004). This representative dataset from the study region helped to establish relationships between pollen spectra composition and modern vegetation, and it was successfully used for interpretation of the Holocene pollen record from the $825 \mathrm{~cm}$ long sediment core $\left(41.89^{\circ} \mathrm{N}, 101.85^{\circ} \mathrm{E} ; 892 \mathrm{~m}\right.$ a.s.l.) from Juyanze palaeolake (Herzschuh et al., 2004). Pollen-based biome reconstruction is a quantitative approach, which was first designed and tested using a limited number of key pollen taxa digitized from the 0 and $6 \mathrm{ka}$ pollen spectra from Europe (Prentice et al., 1996). The method has been further adapted for reconstructing the main vegetation types (biomes) present in northern Eurasia (Tarasov et al., 1998) and in the desert region around the GN200 coring site (Herzschuh et al., 2004). The latter study presents details of the method and the assignment of the terrestrial pollen taxa found in the surface and the Holocene sediment samples from Juyanze core to the respective biomes. In the current study, we apply the same approach and a biome-taxa matrix to the fossil pollen data from the GN200 core as described in Herzschuh et al. (2004).

\subsection{Lipid biomarker analysis}

Twenty-six samples were used for lipid biomarker analysis. The study focused on determining the concentration and downcore distribution of $n$-alkanes in the samples. The $\delta \mathrm{D}$ values of two $n$-alkanes $\left(n \mathrm{C}_{29}\right.$ and $\left.n \mathrm{C}_{31}\right)$ were also measured. Sediment was freeze-dried and homogenized, and 18$42 \mathrm{~g}$ was extracted using a Dionex accelerated solvent extractor 350 with $9: 1$ dichloromethane-methanol (DCM-MeOH, $v: v$ ). The neutral / polar fatty acids and phospholipid fatty acid fractions were isolated from the total lipid extract using an aminopropyl column with 2: 1 DCM-2-propanol, $4 \%$ glacial acetic acid in ethyl ether, and $\mathrm{MeOH}$, respectively. The neutral/polar fraction containing the $n$-alkanes was further separated using an alumina column and 9:1 HexaneDCM. A final clean-up column to further separate the saturated $n$-alkanes was run using hexane and silver nitrate on a silica gel column. A Thermo Trace Ultra ISQ gas chromatograph (GC) mass spectrometer (MS) with flame ionization detection (FID) was used to identify and quantify the $n$-alkanes. Samples were injected in splitless mode at $300^{\circ} \mathrm{C}$ onto a $30 \mathrm{~m}$ fused silica column (Agilent J\&W DB$5,0.25 \mathrm{~mm}$ i.d., $0.25 \mu \mathrm{m}$ film thickness) with hydrogen as the carrier gas. Following a minute hold at $80^{\circ} \mathrm{C}$, the GC oven temperature ramped to $320^{\circ} \mathrm{C}$ at a rate of $13^{\circ} \mathrm{C} \mathrm{min}^{-1}$ and with a final hold of $20 \mathrm{~min}$. The $n$-alkanes were identified by retention times as compared to a standard $n$-alkanes mix and also by MS fragmentation patterns. An internal standard, $5 \alpha$-androstane, was used for compound quantification. The $\delta \mathrm{D}$ values were determined using a Trace $1310 \mathrm{GC}$ coupled to a Finnigan Delta V Plus isotope ratio mass spectrometer (IRMS). Injection conditions and the GC column were identical to measurement on the GC-FID and the oven programme was as follows: $60^{\circ} \mathrm{C}$ isothermal for $1 \mathrm{~min}$, ramp to $320^{\circ} \mathrm{C}$ at $6^{\circ} \mathrm{C} \mathrm{min}-1$, and a $12 \mathrm{~min}$ hold at $320^{\circ} \mathrm{C}$. The $\mathrm{H}_{3}^{+}$factor was determined daily and averaged $4.8 \pm 0.3 \mathrm{ppm} \mathrm{mV}^{-1}$ during the analysis. Minimum peak size used was $2500 \mathrm{mV}$ (amplitude 2). Data were normalized to the Vienna Standard Mean Ocean Water (VSMOW) scale using an A6 $n$-alkane standard mix (Arndt Schimmelmann, Indiana University), injected at the beginning, middle, and end of every run for calibration purposes. Squalane with a known isotopic value was co-injected with samples and A6 standard mix to monitor instrument accuracy and precision, and an in-house $n$-alkane suite was also used to assess instrument conditions. Squalane deviation from the accepted value was $<5 \%$ for all samples and standards analysed. Due to low abundances of other chain lengths, only long-chain $n$-alkanes $\left(n \mathrm{C}_{29}\right.$ and $\left.n \mathrm{C}_{31}\right)$ were measured for $\delta \mathrm{D}$ values. Alkane data are expressed as concentration ( $\mu \mathrm{g} \mathrm{g}^{-1}$ dry weight) and using the following equations.

The average chain length (ACL) quantifies the mean homologue length of a suite of $n$-alkyl compounds. $n$-Alkanes $\left(n \mathrm{C}_{19}\right.$ to $\left.n \mathrm{C}_{33}\right)$ were calculated using Eq. (1). $\mathrm{C}_{i}$ refers to the peak area and $i$ represents the number of carbons of each individual chain length.

$\mathrm{ACL}=\frac{\sum\left(i \times \mathrm{C}_{i}\right)}{\sum \mathrm{C}_{i}}$

$P_{\text {aq }}$ quantifies the relative input of non-emergent macrophytes to emergent macrophytes and terrestrial plants (Ficken et al., 2000). The proxy is calculated by the ratio of the sum of abundances of mid-chain $n$-alkanes to the sum of mid- and long-chain $n$-alkane abundances as shown in Eq. (2):

$$
P_{\text {aq }}=\frac{\mathrm{C}_{23}+\mathrm{C}_{25}}{\mathrm{C}_{23}+\mathrm{C}_{25}+\mathrm{C}_{29}+\mathrm{C}_{31}} .
$$

\subsection{Statistical treatment}

The mineralogical and geochemical data are of compositional nature, which means that they are vectors of nonnegative values subjected to a constant-sum constraint (usually $100 \%$ ). This implies that relevant information is contained in the relative magnitudes, and mineralogical and geochemical data analyses can focus on the ratios between components (Aitchison, 1990). In addition, log transformation 
will reduce the very high values and spread out the small data values, and it is thus well suited for right-skewed distributions (van den Boogaart and Tolosana-Delgado, 2013). Compared to the raw data, the log-ratio scatter plots exhibit better sediment discrimination.

Log ratios can also minimize the problematic issue that element compositional data from XRF measurements have a poorly constrained geometry (e.g. variable water content, grain size distribution, or density) and non-linear matrix effects (Tjallingii et al., 2007; Weltje and Tjallingii, 2008). In addition, they provide a convenient way to compare different XRF records even when measured on different instruments in terms of relative chemical variations. Log ratios of element intensities are consistent with the statistical theory of compositional data analysis, which allows for robust statistical analyses in terms of sediment composition (Weltje et al., 2015).

Prior to PCA (principal component analysis) and $k$-means cluster analyses, a centred-log ratio (clr) transformation was applied to the dataset following Aitchison (1990). This means element ratios were calculated from raw cps (counts per second) values and smoothed with a $5 \mathrm{pt}$ (point) running mean. Thus, cps values were clr transformed (Weltje and Tjallingii, 2008), whereby elements measured with $10 \mathrm{kV}$ (Al, K, Ca, Ti, Mn, Fe) were calculated separately from $30 \mathrm{kV}$ elements (Rb, Sr, S, Zr, Cr, Zn, Br).

\subsection{Chronostratigraphy}

The chronology of core GN200 is derived from magnetostratigraphy. Consolidated sediment samples were cut out manually as specimens and placed in plastic boxes of $1.8 \mathrm{~cm} \times 1.8 \mathrm{~cm} \times 1.6 \mathrm{~cm}$. A total of 567 samples were used. Measurements of the natural remanent magnetization (NRM) and stepwise alternating field (AF) demagnetization were performed at the palaeomagnetic laboratory of Tübingen University using a $2 \mathrm{G}$ enterprises DC-4 K 755 squid magnetometer system with an in-line 3-axial AF demagnetizer. For data visualization and interpretation, the software package Remasoft (Chadima and Hrouda, 2006) was used, applying PCA (Kirschvink, 1980) for determination of palaeomagnetic directions. Because no control of drilling azimuths was available, the analysis and interpretation of palaeomagnetic directions is based solely on inclinations. All specimens were subjected to stepwise AF demagnetization (steps: NRM, 4, 6, $8,10,15,20,25,30,40,50,60,80$, and $100 \mathrm{mT}$ ). Demagnetization runs usually provided interpretable results before reaching the noise level of the magnetometer. The resulting polarity sequence is based on $281 \mathrm{ChRM}$ directions, determined by PCA with a minimum of four consecutive demagnetization steps and mean angular deviation $(\mathrm{MAD})<10^{\circ}$ (Fig. 7). A minimum of two subsequent ChRM directions, with inclinations of less than or greater than $\pm 20^{\circ}$, was required for defining a polarity interval. Where necessary, also PCA components with $\mathrm{MAD}>10^{\circ}$ or with demagnetization paths (for the final component) were used to support the interpretation. Overprints of recent Earth magnetic field (EMF; parallel to normal palaeofield direction), which cannot be separated from the palaeoremanence, lead to better grouping of apparently normal palaeodirections and a more scattered distribution of reverse palaeodirections.

We augment the relative ages of the palaeomagnetic datasets with absolute ages using simple burial dating based on in-situ-produced cosmogenic nuclides (e.g. Balco and Rovey II, 2008; Granger, 2014). Five samples from different depths were sieved, and different grain sizes were cleaned and prepared according to protocols outlined in Schaller et al. (2016). Chemical preparation of the samples was conducted at the University of Tübingen, Germany. ${ }^{10} \mathrm{Be} /{ }^{9} \mathrm{Be}$ and ${ }^{26} \mathrm{Al} /{ }^{27} \mathrm{Al}$ ratios were measured at the AMS facility at Cologne, Germany. The age calculation for simple burial dating is based on a MATLAB script by Schaller et al. (2016). The decay constants used for ${ }^{10} \mathrm{Be}$ and ${ }^{26} \mathrm{Al}$ are $(4.997 \pm$ $0.043) \times 10^{-7}$ (Chmeleff et al., 2010; Korschinek et al., $2010)$ and $(9.830 \pm 0.250) \times 10^{-7}$, respectively (see Norris et al., 1983). We used sea-level-high-latitude (SLHL) production rates of 3.92, 0.012, and 0.039 atoms (g quartz) ${ }^{-1} \mathrm{yr}^{-1}$ for nucleonic, slow-muonic, and fast-muonic ${ }^{10} \mathrm{Be}$ production, respectively (Borchers et al., 2016; Braucher et al., 2011). The SLHL production rates for ${ }^{26} \mathrm{Al}$ are 28.54 , 0.84 , and 0.081 atoms ( $g$ quartz) $)^{-1} \mathrm{yr}^{-1}$ for nucleonic, slowmuonic, and fast-muonic production, respectively (Borchers et al., 2016; Braucher et al., 2011). These production rates result in a SLHL ${ }^{26} \mathrm{Al} /{ }^{10} \mathrm{Be}$ ratio of $\sim 7.4$. We then scaled the SLHL production rates to the sample locations of this study based on the CRONUScalc online calculator of Marrero et al. (2016) using the scaling procedure "SA" from Lifton et al. (2014). Depth scaling of the production rates is based on nucleonic, stopped-muonic, and fast-muonic adsorption lengths, which are 157,1500 , and $4320 \mathrm{~g} \mathrm{~cm}^{-2}$, respectively (Braucher et al., 2011). The density of $2.4 \pm 0.2 \mathrm{~g} \mathrm{~cm}^{-3}$ is assumed to be constant over the depth of the core.

Depth-to-age transformation was carried out by linear interpolation between the ground surface (present) and the core bottom using the palaeomagnetic data; radionuclide results were used for backing up the interpretation.

\section{Results}

\subsection{Sediment stratigraphy}

The studied core GN200 was drilled in 2012 to a depth of $223.7 \mathrm{~m}$; three main sedimentary units are identified in it (Fig. 2). Unit A at the core bottom partially belongs to the regionally widespread Red Clay formation, a set of alternating reddish aeolian sediments and carbonate-rich darkreddish palaeosols of Neogene (Porter, 2007) or Late Cretaceous (Wang et al., 2015) age. The overlying units B and $\mathrm{C}$ represent the Quaternary basin fill and reach a thick- 

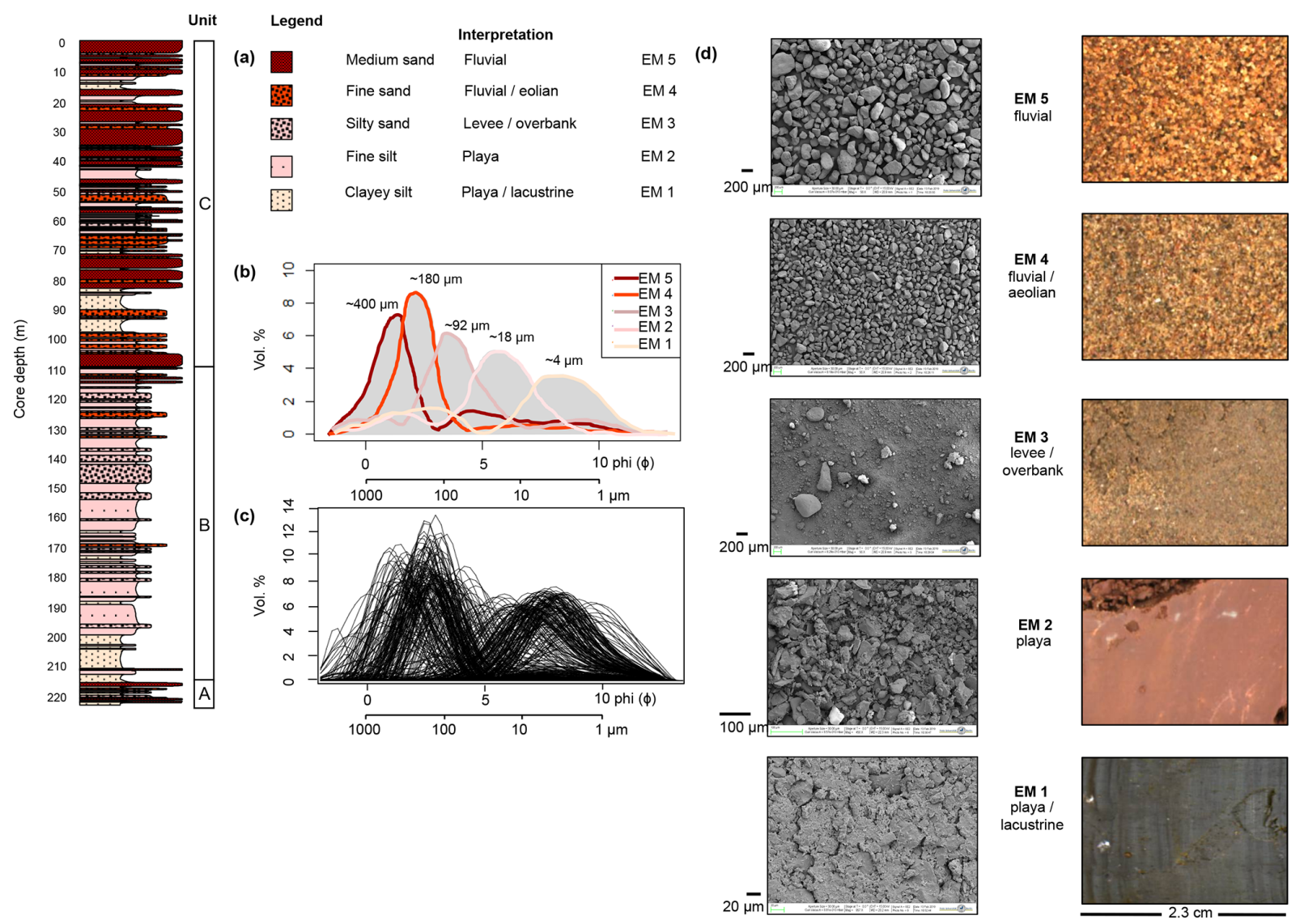

Figure 2. (a) GN200 graphic log with sediment units and litho codes deduced from grain size dominating endmembers (EM) (based on Dietze and Dietze, 2019). Interpretation of depositional environment is added. (b) Illustrated endmember calculation results and (c) sample population (see also Appendix). (d) SEM images and core scan examples for the main sediment types as defined by endmember interpretation.

ness of $222.6 \mathrm{~m}$. From bottom to top, the main macroscopic features are as follows: unit A $(223.7-217.0 \mathrm{~m})$ is dominated by coarse-grained layers (fine- to medium-grained sand) interbedded with fine-grained sediments (clayey silt). Colours change on a sub-metre scale from red and orange in the sandier parts to grey in the silt-rich layers. Sediment change can be both sharp and transitional. Occasionally, centimetre-thick white layers indicate carbonate enrichment in the sandy layers. Unit A includes deposits that are interpreted to belong to the Red Clay formation, i.e. at the core bottom between 223.7 and $222.6 \mathrm{~m}$ red sandy clay with angular clasts occurs, which is interpreted a fanglomerate. This subunit has a sharp boundary with the grey (anoxic) medium sand layers overlying them at $222.66 \mathrm{~m}$ (see also: http://hs.pangaea.de/Images/Cores/ Lz/Gaxun_Nur/GN200_images_31-223m.pdf, last access: 10 April 2020).

Unit B (217.0-110.0 m) has a succession of banked clayey silt with an increasing frequency of intercalated coarser grained layers dominated by very fine sand to fine sand towards the top of the unit. Silt portions can stretch over several metres upcore and turn from grey $(217.0-200.0 \mathrm{~m})$ to brown- olive colours (200.0-177.0 m). Remarkably, sequences of clayey silt between 210.0 and $200.0 \mathrm{~m}$ show successions of millimetre-thick laminations of white and grey-to-orange laminae. Brown to orange colours appear in the middle to upper part of the unit (177.0-110.0 m). Some layers containing coarse sand to very fine gravel form a top subunit (between 120.0-110.0 m). Counts of macrofossils are overall low if samples are not barren at all. Ostracod remains can be found occasionally in layers scattering above $196 \mathrm{~m}$ core depth and up to the top of the unit. They are admixed to greatest extent (to double-digit numbers) in coarse silty sediments; especially at core depths $181.5,138.0-137.0,128.0-127.0$, 121.0 , and at $114.8 \mathrm{~m}$. Gastropod shells are found even more rarely. They are encountered in fine silt at 177.6 and $138.7 \mathrm{~m}$ core depth and in coarse silt layers at 120.6 and $113.7 \mathrm{~m}$ (fine silt). Remarkably, no fossils occur in the laminated fine silt layers between 210.0 and $200.0 \mathrm{~m}$ and between 173.0 and $172.0 \mathrm{~m}$.

Unit C (110.0-0.0 m) is a succession of fine and medium sand layers interbedded with silt banks that decrease in frequency towards the top. The gradational increase in fine silt content in these silt banks is paralleled by a loss of the 
clay fraction. Depending on dominating grain sizes, colours change from yellow, grey, and orange in the sandier layers to light red in the silt banks. At core depths between 28.5 and $27.5 \mathrm{~m}$ and between 10.0 and $7.0 \mathrm{~m}$ black soft mud occurs, which likely represents lake sedimentation. At 103.2, 99.3, 68.6, and $43.2 \mathrm{~m}$ core depths, noteworthy accumulations of ostracod shells were found. Dominating grain size fractions in layers containing ostracods range from coarse silt to fine and medium sand. Gastropod shells were found only in few layers at 103.2, 102.9, and $99.9 \mathrm{~m}$ depth. The dominating grain-size fractions in these sediments range from coarse silt to fine and medium sand.

A graphic log of the sediment column derived from visual logging and EMMA-derived endmember calculations is presented in Fig. 2. For completion, the sample population and EM modelling results are added. Most of the GN200 samples have a polymodal grain size distribution. The EMMA algorithm produces a five-EM model that envelops all main modes. This explains more than $99.6 \%$ of the total variance (see Appendix). EM 5 is associated with medium to fine sand and a primary mode at $\sim 400 \mu \mathrm{m}$ and a subordinate mode at $37 \mu \mathrm{m}(8.6 \%)$; EM 4 represents fine sand with the main mode at $180 \mu \mathrm{m}(34 \%)$; EM 3 is composed of silty sand with the main mode at $92 \mu \mathrm{m}(11 \%)$; EM 2 is composed of medium silt with a primary mode at $18 \mu \mathrm{m}$ and a subordinate mode at $360 \mu \mathrm{m}(27 \%)$. Remarkably, EM 2 is similar to EM 5 but with reverse order of mode precedence. EM 1 is composed of clayey silt with a main mode at $4 \mu \mathrm{m}$ and a subordinate fine sand fraction admixed (19\%). Surficial processes and landforms producing sediments as found in GN200 are typically fluvial, fluvial-aeolian, levee, and overbank deposition; sheetflood and surface wash (playa); and lacustrine processes (e.g. Zhu et al., 2015). Apart from unit A, the frequency of coarse-grained (sand-dominated) layers generally increases from the bottom of unit B to the top of unit A. The appearance of the first prominent sand layer that is several metres thick in size is used to set the boundary between the two units $\mathrm{B}$ and $\mathrm{A}$.

\subsection{Dating from palaeomagnetism and radionuclide concentrations}

NRM intensities ranged from $0.01-4.2 \mathrm{~mA} \mathrm{~m}^{-1}$ with a median of $1.6 \mathrm{~mA} \mathrm{~m}^{-1}$. Most samples exhibited onecomponent-like or two-component-like demagnetization behaviour. AF demagnetization characteristics and thermomagnetic runs proved magnetite as the main magnetic carrier of the characteristic remanent magnetization (ChRM). The polarity sequence from core GN200 starts at the top with normal polarity and has several longer intervals of reverse polarity further downcore between ca. 60-80, 100-135, and 170$225 \mathrm{~m}$ (Fig. 3). Given that during the Brunhes chron only few very short events of reverse polarity have occurred (Singer, 2014; Cohen and Gibbard, 2019), which cannot explain any longer intervals of reverse polarity, the polarity boundary at ca. $60 \mathrm{~m}$ can be correlated to the Brunhes/Matuyama (B/M) boundary $(0.773 \mathrm{Ma})$. Locating the exact position of the $\mathrm{B} / \mathrm{M}$ boundary in the record, however, may be a matter of discussion. The EMF behaviour at the B/M boundary is obviously rather complex (Singer, 2014), and the limitations of the sampling (no azimuths) and demagnetization procedures (no thermal demagnetization possible) do not allow us to disentangle the effects of palaeofield behaviour, lockin-mechanism, or to separate different palaeofield and recent field components completely. In most of the downcore normal polarity intervals, AF demagnetization of specimens looks like a one-component behaviour, whereas in reverse intervals and near reversals it frequently appears more complex and may exhibit two components of magnetization, which cannot be separated sufficiently. From about 55 to $60 \mathrm{~m}$, shallow normal and reverse components with inclinations $<20^{\circ}$ can be observed in many samples. Slightly changing the criteria for defining polarity intervals could shift the polarity boundary (B/M boundary) close to $55 \mathrm{~m}$. Based on the polarity pattern and assuming sediment accumulation rates of similar magnitude, the well-defined intervals of normal polarity at about $85-95$ and $150-170 \mathrm{~m}$ may be tentatively correlated to the Jaramillo (0.988-1.072 Ma) and Olduvai (1.788$1.945 \mathrm{Ma}$ ) sub-chrons. However, it is unclear whether two very short intervals of normal polarity at around 115 and $125 \mathrm{~m}$ represent palaeofield behaviour or are artefacts caused by recent field overprints. The lowermost part of the drill core between 172.0 and $222.6 \mathrm{~m}$ shows reverse polarity, which is separated by a hiatus from the rest of the polarity sequence.

Burial dating based on in-situ-produced cosmogenic nuclides provides three out of six measurements of ${ }^{10} \mathrm{Be}$ and ${ }^{26} \mathrm{Al}$ concentrations, which have produced reliable results; namely GN200 19a, GN200 21a, GN200 34b (Tables 1 and 2 ). In contrast, the remaining three samples produced signals close to blank and are discarded from interpretation (GN200 68a, GN200 102a, GN200 102a, Tables 1 and 2). The samples from core depths $19.1 \mathrm{~m}, 20.3 \mathrm{~m}$, and $53.1 \mathrm{~m}$ had quartz portions high enough for robust measurements (Tables 1 and 2). The upper two samples have yielded ages $>2 \mathrm{Ma}$, the one at $53.1 \mathrm{~m}$ core depth has an age of $0.84 \pm 0.12 \mathrm{Ma}$ (Fig. 4). Given the error bar of the $53.1 \mathrm{~m}$ sample $(0.84 \pm 0.12 \mathrm{Ma})$, the radionuclide age overlaps with the Brunhes/Matuyama boundary ( $0.773 \mathrm{Ma})$ on the geomagnetic timescale and which itself has an error bar of $\pm 1 \%$ at this chron boundary (Singer, 2014). If this geochronological interpretation is true, it would back up the prominent $20 \mathrm{~m}$ thick event with negative inclination below $60 \mathrm{~m}$ core depth as belonging to the Matuyama chron.

From magnetostratigraphy, the first-order depth-to-age relationship produces a mean sedimentation rate of $9 \mathrm{~cm} \mathrm{kyr}^{-1}$ during the last $2.58 \mathrm{Ma}$ in the Ejina Basin (Fig. 4). This assumes an overall balanced change of accumulation and erosion across glacial-interglacial cycles in the area. If the radionuclide dating at $53.1 \mathrm{~m}(0.84 \pm 0.12 \mathrm{Ma})$ is included, this sedimentation rate slightly decreases to $6 \mathrm{~cm} \mathrm{kyr}^{-1}$ in the up- 
Inc. $\left({ }^{\circ}\right) \quad$ Polarity $\quad$ GPTS $(\mathrm{Ma})$

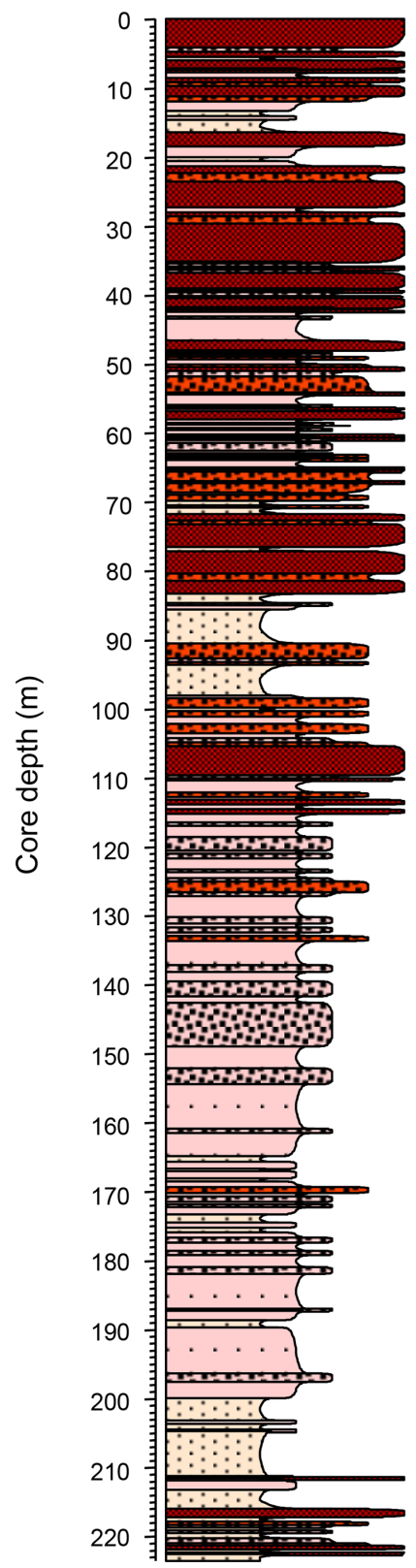

$90-45 \quad 0 \quad 4590$

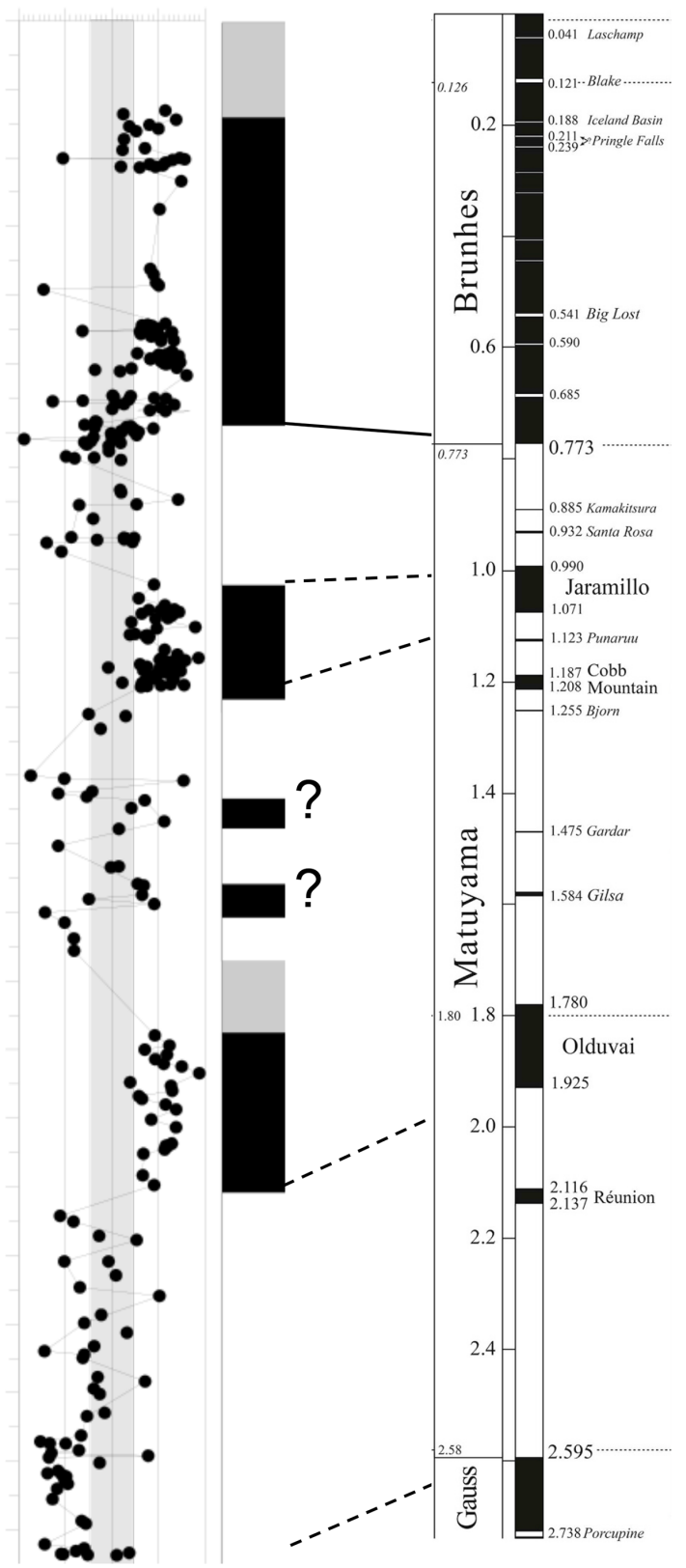

Figure 3. Litho- and magnetostratigraphy of core GN200. The geomagnetic polarity timescale (GPTS) is from Cohen and Gibbard (2019).

per $53 \mathrm{~m}$, whereas the lower $169 \mathrm{~m}$ core have a slightly increased sedimentation rate of $10 \mathrm{~cm} \mathrm{kyr}^{-1}$.

\subsection{Bulk sediment properties}

The graphic log of the GN200 sediment column is combined with downcore XRF element distribution in Fig. 5. From the bottom to the top, elemental relative concentrations show those sandy sediments of unit A are Al-K dominated, whereas fine silty lacustrine deposits at the bottom of unit B are more $\mathrm{Mn}$ and $\mathrm{K}-\mathrm{Al}$ dominated. Playa deposits in the lower part of unit B can be characterized by Ca-Tior by Al-K-dominated sediments. The upper part of unit B holds an alternation of $\mathrm{Mn}$ and Al-K-dominated sediments. In unit $\mathrm{C}$ sediments change from the $\mathrm{Al}-\mathrm{K}$ type to greater portions of Ca-Ti-dominated sediments. PCA calculations from $10 \mathrm{kV}$ XRF data (i.e. the main siliciclastic components $\mathrm{K}$, $\mathrm{Ca}, \mathrm{Ti}, \mathrm{Mn}$, and $\mathrm{Fe}$ ) reveal that $\mathrm{Ca}$ and $\mathrm{Ti}$ define the first principal component explaining $40.2 \%$ of the total variance. 
Table 1. Information for burial ages from drill core GN200.

\begin{tabular}{llrrrr}
\hline Sample & Lab ID & $\begin{array}{r}\text { Grain size, } \\
\mu \mathrm{m}\end{array}$ & $\begin{array}{r}\text { Depth, } \\
\mathrm{m}\end{array}$ & ${ }^{26} \mathrm{Al} /{ }^{10}$ Be ratio & $\begin{array}{r}\text { Burial age }^{\mathrm{a}}, \\
\text { Ma }\end{array}$ \\
\hline GN200 19a & GN6 & $125-500$ & $19.1 \pm 0.1$ & $2.12 \pm 0.15$ & $2.12 \pm 0.15$ \\
GN200 21a & GN7 & $125-500$ & $20.3 \pm 0.1$ & $1.74 \pm 0.11$ & $2.52 \pm 0.07$ \\
GN200 34b & GN8 & $125-500$ & $53.1 \pm 0.1$ & $3.97 \pm 0.37$ & $0.84 \pm 0.12$ \\
GN200 68a $a^{b}$ & GN1 & $125-250$ & $129.2 \pm 0.3$ & $2.42 \pm 0.70$ & $1.86 \pm 0.43$ \\
GN200 102a ${ }^{b}$ & GN2 & $250-500$ & $217.6 \pm 0.1$ & $2.61 \pm 0.53$ & $1.70 \pm 0.13$ \\
GN200 102a ${ }^{b}$ & GN3 & $125-250$ & $217.6 \pm 0.1$ & $4.73 \pm 1.05$ & $0.48 \pm 0.21$ \\
\hline
\end{tabular}

${ }^{\mathrm{a}}$ Calculated simple burial-age-based concentrations in Table 2. ${ }^{\mathrm{b}}$ Sample with ratios close to blank and high errors. Interpretation of burial age with caution.

Table 2. Analytical information for burial age calculations.

\begin{tabular}{|c|c|c|c|c|c|c|c|c|c|c|}
\hline Sample & Lab ID & $\begin{array}{r}m_{(\mathrm{qtz})} \\
\mathrm{g}\end{array}$ & $\begin{array}{r}{ }^{27} \mathrm{Al} \mathrm{Conc.}, \\
\text { ppm }\end{array}$ & ${ }^{26} \mathrm{Al} /{ }^{27} \mathrm{Al}^{\mathrm{a}}$ & $\begin{array}{r}\text { Error, } \\
\%\end{array}$ & $\begin{array}{r}{ }^{26} \mathrm{Al} \mathrm{Conc.}(\text { corr })^{\mathrm{b}} \\
10^{3} \text { atoms (g quartz) }\end{array}$ & $\begin{array}{r}{ }^{9} \mathrm{Be}^{\mathrm{c}}, \\
\mathrm{mg}\end{array}$ & ${ }^{10} \mathrm{Be} /{ }^{9} \mathrm{Be}^{\mathrm{d}}$ & $\begin{array}{r}\text { Error, } \\
\%\end{array}$ & $\begin{array}{r}{ }^{10} \text { Be Conc. (corr) }{ }^{\mathrm{e}}, \\
10^{3} \text { atoms (g quartz) }\end{array}$ \\
\hline GN200 19a & GN6 & 22.34 & 78 & $1.28 \mathrm{E}-13$ & 5.4 & $221.96 \pm 12.01$ & 0.3307 & $1.07 \mathrm{E}-13$ & 4.4 & $104.79 \pm 4.68$ \\
\hline GN200 21a & GN7 & 75.24 & 94 & $6.82 \mathrm{E}-14$ & 5.4 & $143.02 \pm 7.78$ & 0.3298 & $2.81 \mathrm{E}-13$ & 3.7 & $82.00 \pm 3.03$ \\
\hline GN200 $68 \mathrm{a}^{\mathrm{f}}$ & GN1 & 47.14 & 117 & $3.40 \mathrm{E}-15$ & 26.0 & $8.89 \pm 2.31$ & 0.3284 & $8.60 \mathrm{E}-15$ & 9.6 & $3.67 \pm 0.45$ \\
\hline GN200 $102 a^{\mathrm{f}}$ & GN2 & 12.86 & 119 & $2.19 \mathrm{E}-14$ & 17.0 & $58.14 \pm 9.87$ & 0.3287 & $1.38 \mathrm{E}-14$ & 10.0 & $22.27 \pm 2.51$ \\
\hline GN200 $102 a^{f}$ & GN3 & 19.78 & 121 & $1.33 \mathrm{E}-14$ & 16.8 & $36.08 \pm 6.04$ & 0.3278 & $7.60 \mathrm{E}-15$ & 11.1 & $7.63 \pm 1.10$ \\
\hline
\end{tabular}

${ }^{\text {a }}{ }^{26} \mathrm{Al} /{ }^{27} \mathrm{Al}$ ratios measured against KN01-5-3 and KN01-4-3 (Nishiizumi, 2004). ${ }^{\mathrm{b}}$ No correction for a ${ }^{26} \mathrm{Al}$ chemistry blank. ${ }^{\mathrm{c}}$ Phenakite carrier of GFZ Potsdam. ${ }^{\mathrm{d}}{ }^{10} \mathrm{Be} /{ }^{9} \mathrm{Be}$ ratios measured against KN01-6-2 and KN01-5-3 (Nishiizumi et al., 2007). ${ }^{\mathrm{e}}$ Corrected for a ${ }^{10}$ Be chemistry blank of $(1.98 \pm 0.59) \times 10^{4}$ atoms. ${ }^{\mathrm{f}}$ Sample with ratios close to blank level and high errors. Interpretation of burial ages with caution.

The second component is described by $\mathrm{Al}$ and Mn explaining $29.3 \%$. Ca likely reflects a combination of carbonate (detrital or authigenic) content and feldspar composition. In this way it can highlight both fine-grained and coarse-grained sediments. The $\mathrm{Ca} / \mathrm{Ti}$ ratio illustrates that $\mathrm{Ti}$ is enriched especially in unit $\mathrm{A}$ as also is the case with $\mathrm{K}$. Mn is depleted when compared with the overlying sediments of unit $\mathrm{B}$ and unit A. Within unit B, Ca most prominently dominates sediment layers between 182 to $165 \mathrm{~m}$. Further upcore there are individual layers in unit $\mathrm{C}$ at $105-102,91$, and $68 \mathrm{~m}$, where $\mathrm{Ca}$ distinctly dominates over $\mathrm{Ti}$.

Remarkably, the variability of $\mathrm{K}$ is increased when more sandy sediments are intercalating with playa deposits; this is valid between 175 and $165 \mathrm{~m}$ and for most of unit C. Mn excursions are paralleled by enrichment in $\mathrm{S}$ and distinct peaks in magnetic susceptibility. This is particularly true for the lacustrine sediments at the bottom of unit B and playa sediments in the middle part of unit B between 168 and $159 \mathrm{~m} . \mathrm{S}$ is also enriched between 105 and $102 \mathrm{~m}$, in this case without a marked occurrence of $\mathrm{Mn}$ and magnetic susceptibility but paralleled by peaks of $\mathrm{Ca}$.

As for unit B, counts of macrofossils are overall low in unit $\mathrm{C}$ if samples are not barren at all. Ostracods are especially found in double-digit numbers at core depths 103.8, 68.6, 43.4-43.3, 38.7, 38.1, 37.6, 34.9, 33.9, and $31.9 \mathrm{~m}$. Gastropods are found in considerable double-digit numbers only in sandy to silty sediments between 103.9 and $99.9 \mathrm{~m}$ depth (Fig. 5).
Bulk mineralogical composition is characterized by high counts of quartz and feldspar in unit A (Fig. 6). Feldspar is relatively enriched over quartz when compared with units $\mathrm{B}$ and C. Dolomite is decreased with respect to calcite in unit A when compared to units B and C. Mineralogical differences between units $\mathrm{B}$ and $\mathrm{C}$ are less distinct but best expressed with lower quartz and feldspar amounts in B than in C, where the frequency of sandy layers increases. Hornblende and dolomite do not have distinct trends, but show individual peaks scattered in units B and C. They appear to be connected to individual sediment layers, i.e. hornblende at $171.0 \mathrm{~m}$ and dolomite at $77.0 \mathrm{~m}$. Calcite is found nearly continuously in unit $\mathrm{B}$ with respect to the average of all inspected minerals. Towards the upper $40 \mathrm{~m}$ of unit $\mathrm{C}$, which are dominated by a succession of sand layers, the calcite amount decreases.

Smectite in the clay mineral record clearly increases in playa lake sediments of unit B (Fig. 7). In contrast, mixedlayer minerals (i.e. chlorite/smectite) have peak occurrence only in unit C, where kaolinite is low. In units B and C, kaolinite is non-conclusive as is chlorite at a first glance. However, there is an upcore trend towards higher chlorite amounts: between 223.7 and $130.0 \mathrm{~m}$ the average is $20 \%$, whereas above $130.0 \mathrm{~m}$ core depth it increases to $27 \%$.

\subsection{Pollen record}

Microscopic analysis of the 62 processed samples showed that only 21 samples had sufficiently high pollen concentrations and were suitable for further pollen counting and in- 


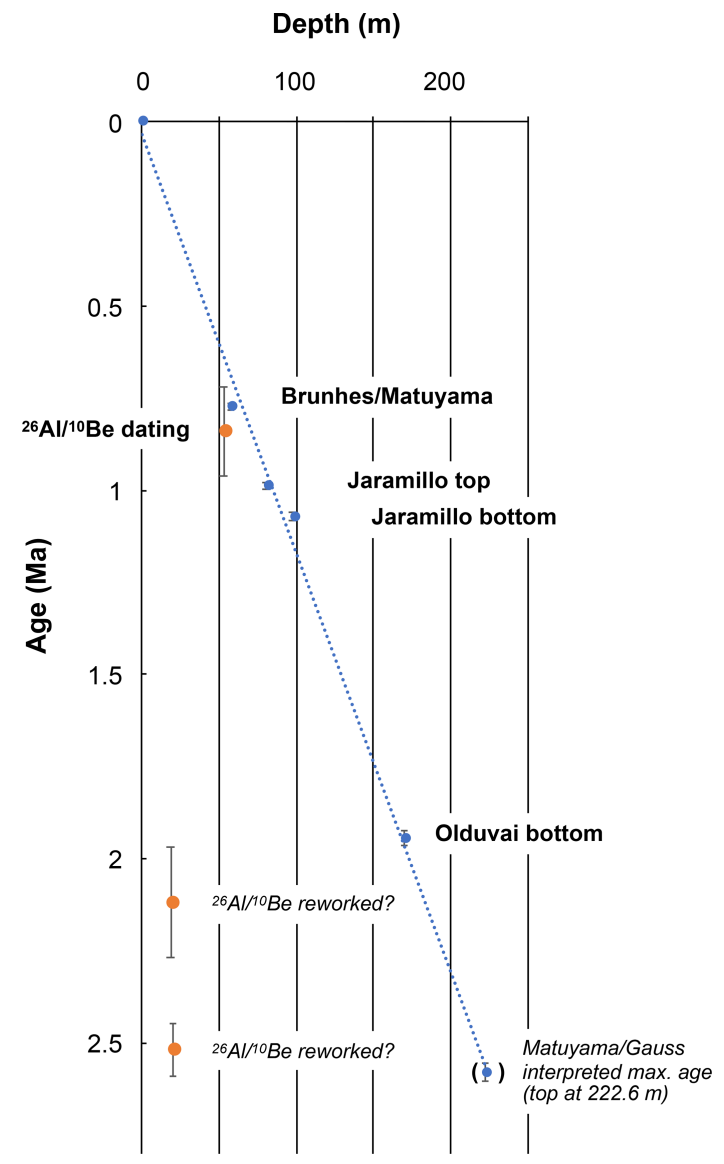

Figure 4. Age-depth relation in core GN200. The age model is related to the interpreted magnetostratigraphy. Radionuclide datings are given in addition. For more discussion see the text.

terpretation of palaeoenvironments. The remaining 41 samples showed the absence or very few pollen grains. The 21 counted samples are scattered over four depth intervals: 160.07-168.46, 193.86, 197.68-203.41 and 207.3-217.02 m. The identified pollen and non-pollen palynomorphs include 49 terrestrial taxa (trees, shrubs, forbs, herbs, sedges, and grasses), 2 taxa representing aquatic plants, 4 types of algae remains as well as fern spores. The main results of pollen analysis and pollen-based biome reconstruction are shown in the summary diagram (Fig. 8).

The core interval $217.02-207.3 \mathrm{~m}$ represents the period between ca. 2.523 and $2.410 \mathrm{Ma}$. The nine analysed samples from this interval show relatively high pollen concentrations, which range from 13738 to 106543 grains per gram. Among 42 identified taxa, desert taxa such as Chenopodiaceae (62\%-78\%), Ephedra (up to 19\%), and Nitraria $(0.5 \%-1.8 \%)$ are absolutely dominating the pollen assemblages. Arboreal taxa representing the mountain forest include Pinus (up to 6.4\%), Picea, Abies, and Betula, while Ulmus (up to 9.6\%), Salix, Hippophae, and Elaeagnus represent riparian forest communities. Poaceae pollen does not

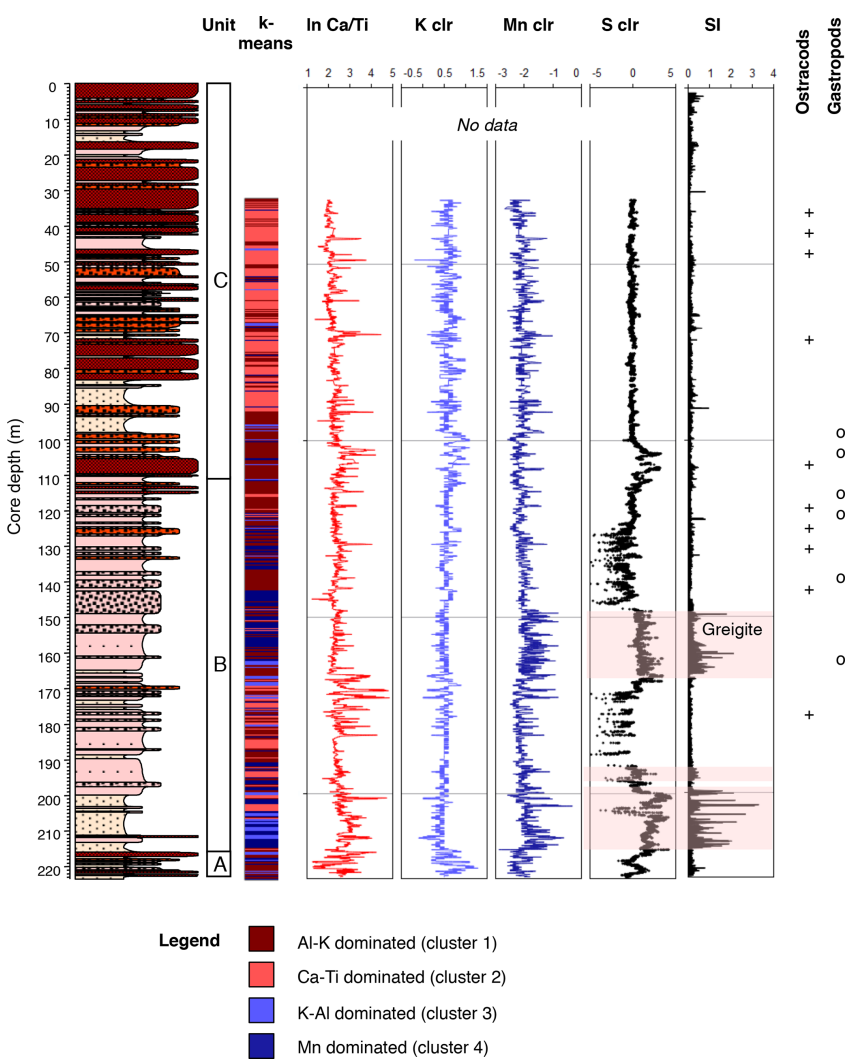

Figure 5. GN200 core with selected XRF elemental distribution, magnetic susceptibility (SI), and presence of ostracods and gastropods. $S_{\mathrm{clr}}$ has been calculated from $30 \mathrm{kV}$ elements. Interpreted greigite occurrence is marked in addition $(\mathrm{clr}=$ centred-log ratio).

occur regularly and never exceeds $2 \%$. Pollen of Sparganium $(2 \%-8 \%)$ is found in all samples and represents the aquatic shallow-water environments, along with the remains of algae. The arboreal pollen from the mountain forests makes a relatively small contribution to the pollen assemblages, which probably reflect a greater-than-present distance to these forests and/or even lesser area occupied by coniferous and birch trees.

The core interval $203.41-197.68 \mathrm{~m}$ represents the period between ca. 2.363 and $2.294 \mathrm{Ma}$. Four samples were counted from this interval. The pollen concentration is relatively low (from 3569 to 4720 grains per gram) and increases to 12834 grains per gram in sample 63 (Fig. 8). A total of 39 taxa were determined. The percentages of Chenopodiaceae (19\%-64\%) and Ephedra (2.5\%-15\%) pollen decrease towards the top. Among the temperate deciduous tree taxa, $B e$ tula dominate (up to $26 \%$ ), followed by Ulmus (up to $15 \%$ ) in the two upper samples. Abies pollen (4\%) is only found in the uppermost sample 61. The samples contain pollen of aquatic taxa such as Sparganium (up to 6\%) and Typha latifolia (up to $10 \%$ ) and the remains of green algae. Riparian vegetation and taxa of mountain forests are much bet- 


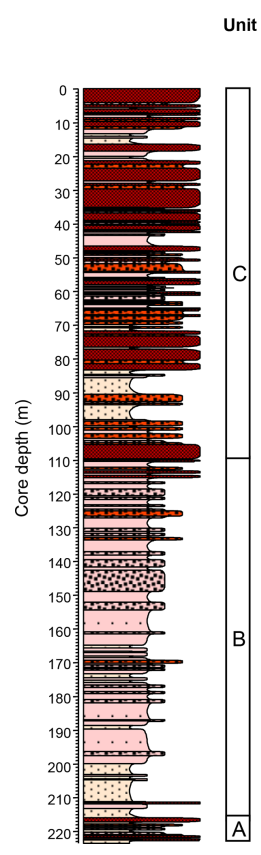

Qz+Fsp/clay Plag/Qz Hb/Qz Do/Cc Cc clr

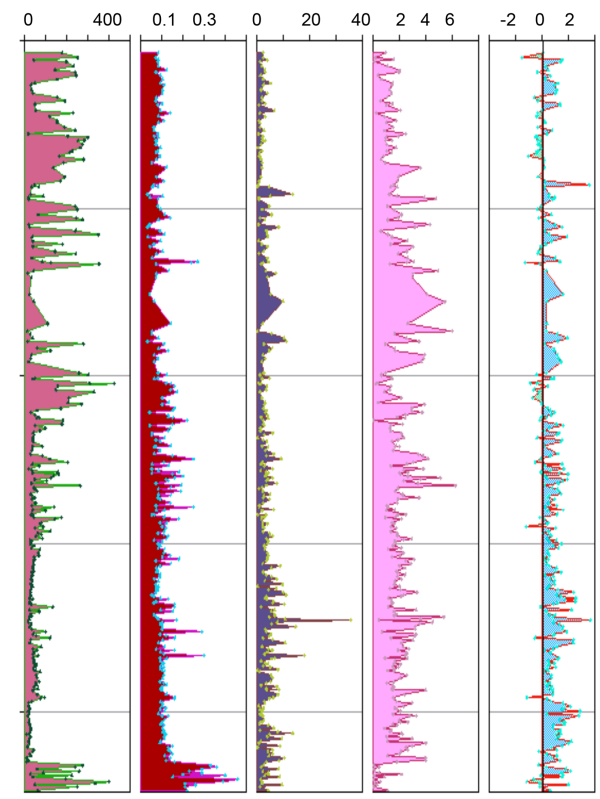

Figure 6. GN200 core with mineral distributions from XRD bulk measurement. Qz = quartz, Fsp = feldspar, Plag = plagioclase, $\mathrm{Hb}=$ hornblende, $\mathrm{Do}=$ dolomite, $\mathrm{Cc}=$ calcite $\quad(\mathrm{clr}=$ centred-log ratio).

ter represented in the pollen assemblages dated to ca. 2.3172.294 Ma.

The same trend is observed in sample 60 from a depth of $193.86 \mathrm{~m}$ (Fig. 8), which dates to 2.249 Ma. The pollen concentration is 4720 grains per gram. Ulmus $(16.9 \%)$ remains the most visible taxon of the riparian forest, while Picea $(12.1 \%)$, Betula $(15.5 \%)$, and Pterocarya $(5.8 \%)$ represent the mountain forest community. Ephedra pollen is relatively rare $(3.4 \%)$ and Chenopodiaceae values are close to minimal $(29 \%)$ in the entire record. Typha latifolia pollen reaches a maximum $(11.5 \%)$ in this sample.

In the interval $168.46-160.07 \mathrm{~m}$, seven samples representing the time period between ca. 1.954 and $1.857 \mathrm{Ma}$ were counted. With the exception of sample 5 (15979 grains per gram), pollen concentrations are low (1449-3584 grains per gram). Among the 40 taxa identified, the arboreal taxa are still abundant, including Pinaceae (18\%), Betula (up to $12 \%$ ), Picea (up to $12 \%$ ), and Pinus (up to $9 \%$ ). However, Chenopodiaceae (29\%-54\%) and Ephedra (up to 17\%) increase in abundance. The largest share of algae can be traced to Botryococcus (up to $12 \%$ ). Sample 5 at a depth of $166.92 \mathrm{~m}$, dated to about $1.935 \mathrm{Ma}$, shows a relatively high pollen concentration and a very high proportion of Chenopodiaceae $(76 \%)$ and Ephedra (11\%) and largest number of corroded pollen grains.

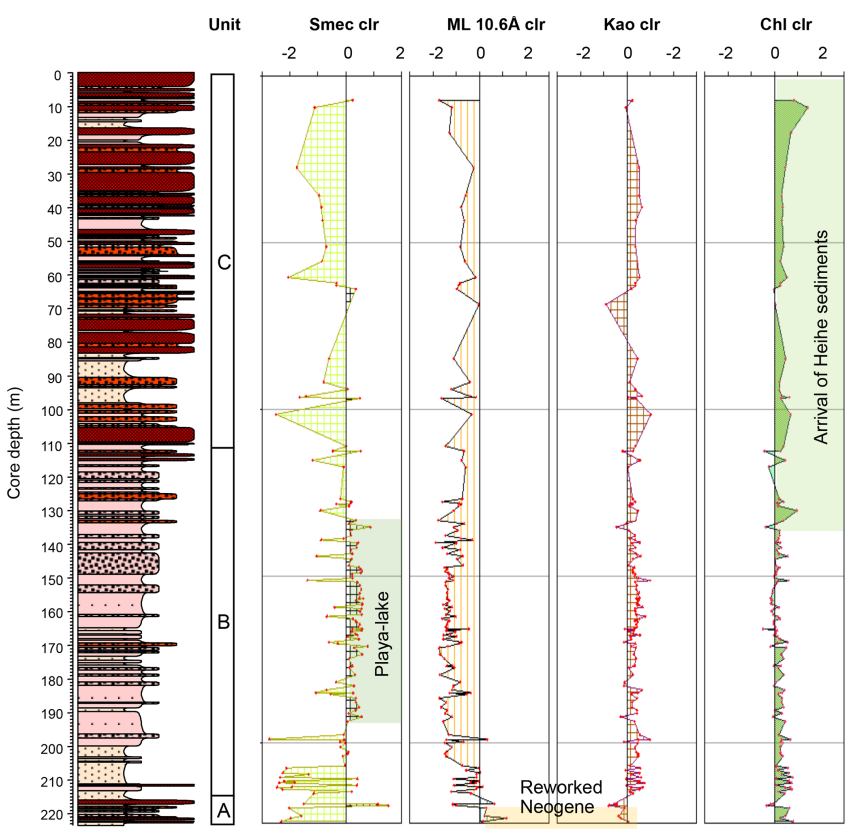

Figure 7. GN200 core with clay mineral distribution and interpretative labels. $\mathrm{Smec}=$ smectite, $\mathrm{ML}=$ mixed-layer minerals, $\mathrm{KaO}=$ kaolinite, $\mathrm{Chl}=$ chlorite $(\mathrm{clr}=$ centred-log ratio $)$.

\section{$4.5 \quad n$-Alkane abundances and $\delta \mathrm{D}$ record}

Evidence for hydroclimate-driven vegetation change in the Ejina Basin is provided from biomarker data (Fig. 9).

The short-chain $n \mathrm{C}_{19} n$-alkane is most abundant between core depths 64 to $44.1 \mathrm{~m}$. Concentrations, however, are low and range between 0.048 and $0.068 \mu \mathrm{g}$ (g dry weight $)^{-1}$ of sediment. Mid-chain $n$-alkanes such as $n \mathrm{C}_{23}-n \mathrm{C}_{25}$ can be found in samples between 217 to $44.1 \mathrm{~m}$ and have higher concentrations with a maximum value of $0.123 \mu_{\mathrm{g} \mathrm{g}}^{-1}$ dry weight occurring at $159.2 \mathrm{~m}$ depth. Long-chain $n$-alkanes $n \mathrm{C}_{27}-n \mathrm{C}_{33}$ are dominant with a maximum value of $0.928 \mu \mathrm{g}$ (g dry weight $)^{-1}$ at $215.45 \mathrm{~m}$ core depth. We examine $P_{\mathrm{aq}}$, which is a proxy ratio that highlights the terrestrial, emergent aquatic, and submerged aquatic macrophyte origins of the lipids (Ficken et al., 2000). With a few exceptions, much of the record has low $P_{\mathrm{aq}}$ values around 0.1 , indicating that the $n$-alkanes likely originate from terrestrial rather than aquatic sources (Fig. 9).

The $\delta \mathrm{D}$ values of long-chain terrestrially derived leaf-wax $n$-alkanes show a strong linear relationship to precipitation $\delta \mathrm{D}$ values across a wide range of environments (Sachse et al., 2004, 2012; Hou et al., 2008). In the nearby Quidam Basin, Koutsodendris et al. (2018) interpreted $\delta \mathrm{D}$ of $n$-alkanes as sensitive recorders of palaeoclimatic variability, particularly sensitive indicators of temperature and moisture source variability (Gat, 1996; Sachse et al., 2012; Yao et al., 2013). Here, $\delta \mathrm{D}$ measurements based on leaf-wax $n \mathrm{C}_{29}$ and $n \mathrm{C}_{31}$ alkanes yielded $\delta \mathrm{D}$ values between $-189 \%$ and $-148 \%$ o 
and $-184 \%$ and $-148 \%$, respectively. The $\delta \mathrm{D}$ wax values from the $n \mathrm{C}_{29}$ and the $n \mathrm{C}_{31}$ alkanes are highly correlated $\left(r^{2}=0.95\right)$, which suggests a similar origin and is thought to be from terrestrial plants.

\section{Discussion}

Earth surface dynamics include a variety of processes that result in mixing of grain size subpopulations in sedimentary systems. Sediment from different sources can be transported and deposited by a multitude of sedimentological processes that have been linked to climate, vegetation, geological, and geomorphological dynamics as discussed in Dietze and Dietze (2019). The record from core GN200 has variable grain size distributions (Fig. 2c) indicating various transport processes that have shaped the depositional environment in the endorheic Ejina Basin. The interpreted endmembers fluvial, aeolian, playa (or sheetflood), and lacustrine processes have smooth transitions reflecting several energy regimes as is typical for desert and alluvial fan environments (Blair and McPherson, 1994). Only recently Yu et al. (2016) described alluvial gravels, fluvial sands, aeolian sand, sandy loess, and lacustrine clays as main sediment types that can be found in the Ejina Basin. Interpretations of nearby cored sediments (230 m long core D100) have related the coarsegrained portions - resembling EM 5 in GN200 - to highenergy fluvial transport from local areas such as the northern (Gobi Altay-Tien Shan range) and western (Beishan) catchment of the basin (Wünnemann et al., 2007b). Following this study, well-sorted fine sand as found in core D100 resembles EM 4 in GN200 and is likewise interpreted as being of aeolian to fluvial origin. Coarse and fine silt deposits resemble EM 3 and EM 2 and indicate playa-like depositional environments under different energy systems. Successions of finer to coarser silt layers building up much of unit B suggest that the depositional processes involved alternating hydrological conditions. Possibly this includes occasional desiccation events in the playa plain as is visible from individual layers of well-sorted fine sand, which suggest aeolian deposition at the site. The entire absence or very poor preservation of pollen in 41 out of 62 selected samples taken from a $57 \mathrm{~m}$ section, mainly representing this playa-like sedimentation environment, confirms our interpretation. On the other hand, bioindicators such as ostracods and gastropods document temporarily subaquatic conditions as are found in ponds and playa lakes. Ostracod communities are dominated by Ilyocypris sp., which prefers fresh- to brackish-water habitats (Mischke, 2001; Yan, 2017). A high abundance of ostracod valves can be evidence for short transport with a proximate burial (Mischke, 2001). Gastropods are represented by Radix peregra, which thrives in waters with a salt content of up to $33.5 \%$ (Verbrugge et al., 2012). This is also true for unit B sediments, which are interpreted to represent playa-lake environmental conditions.
Formation and transformation of clay minerals in soil profiles and regoliths is determined by an interaction between the geology, drainage control by geomorphology, and the climate of the source terrain (Singer, 1984; Hillier, 1995; Wilson, 1999; Dill, 2017). Tracking clay mineralogical changes in the detrital sedimentary compositions of the Ejina Basin by means of XRD data thus can aid the interpretation of environmental changes. Variations in the Ejina Basin clay mineralogy appear to be closely linked to main changes in depositional environments: mixed-layer clays characterize sediment layers belonging to the Red Clay formation (223.7$222.6 \mathrm{~m}$ ) and overlying deposits that have incorporated reworked portions of it (222.6-217.0 m) (unit A), smectiterich clay characterizes the playa environment (large parts of unit B), and chlorite-rich clays are transported with Heihe river sediments (unit $\mathrm{C}$ with overlap to unit $\mathrm{B}$ ).

Complementary detrital and authigenic signals of sediment origin are preserved in the bulk XRD and XRF data and can support the interpretation of sediment environments (e.g. Hillier, 2003; Jeong, 2008; Song et al., 2009). As with the clay signals the unit A sediments, which belong to the Red Clay formation, are well defined by XRD bulk data; i.e. unit $\mathrm{A}$ is markedly dominated by quartz and feldspar when compared with unit B and unit C (Fig. 6).

SEM and XRD analyses of samples with higher concentrations of sulfur from nearby core D100 yielded evidence of gypsum formation when sulfur increased (Wünnemann et al., 2007a). It has been interpreted as pointing to a stepwise shrinkage of the water body under dry and warm conditions. Within the playa-lake succession in unit B prominent peaks of magnetic susceptibly along with sulfur likely indicate greigite $\left(\mathrm{Fe}_{3} \mathrm{~S}_{4}\right)$ formation (Fig. 5). Preservation of greigite can occur in terrigenous-rich and organic-poor sediments, and it is proposed to result from a dominance of reactive iron over organic matter and/or hydrogen sulfide, which otherwise would favour pyritization reactions (Blanchet et al., 2009). In fact, unit B sediments do not contain organic matter based on a set of TOC measurements using an elemental analyser, which produced results only below the detection limit of $0.1 \%$ scattered over the unit (not displayed).

The record of $n$-alkanes suggests large glacial and interglacial variability preserved in the record. The concentration and distribution of $n$-alkanes allow for insight into the vegetation dynamics in the Ejina Basin and its catchment. Plants produce a waxy coating on the surface of their leaves that protects them from desiccation (Eglinton and Hamilton, 1967). These waxes can be transported by wind or water to the sediments where they are robust over geologic timescales (Eglinton and Hamilton, 1967). While long carbon chain lengths are commonly more dominant in terrestrial higher plants $\left(n \mathrm{C}_{27}-n \mathrm{C}_{35}\right)$, aquatic algae and microbes are often predominantly composed of shorter chain lengths $\left(n \mathrm{C}_{17}-n \mathrm{C}_{21}\right)$ (Ficken et al., 2000). The mid-chain length homologues $n \mathrm{C}_{23}-n \mathrm{C}_{25}$ often produced in smaller quantities by terrestrial higher plants, are often found in abun- 


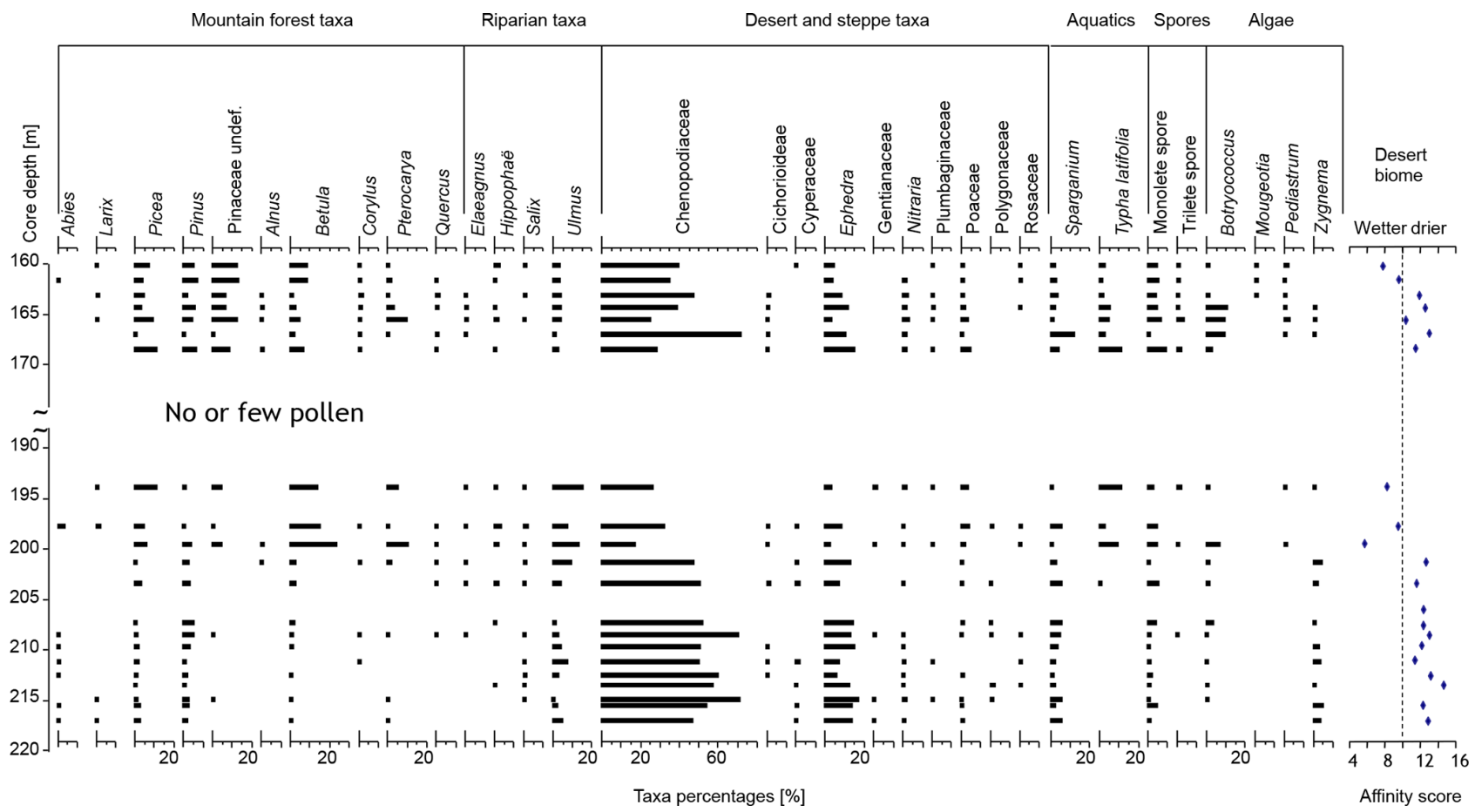

Figure 8. Percentage pollen diagram summarizing the results of pollen analysis presented in this study. The biome score calculation of the dominant desert biome uses the approach and pollen taxa to biome attribution described in Herzschuh et al. (2004).

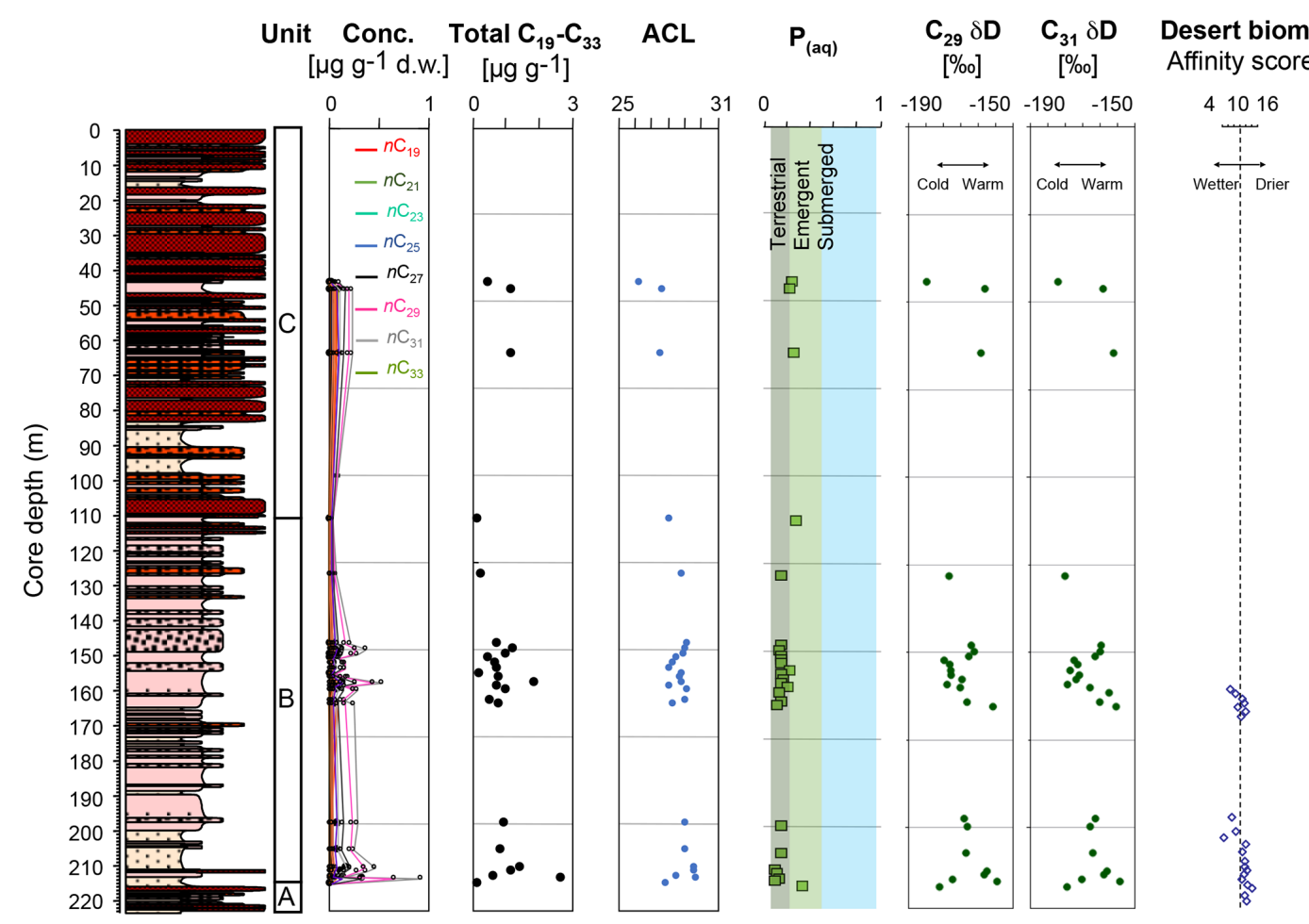

Figure 9. GN200 core with concentrations of $n$-alkanes (d.w. = dry weight) and average chain length (ACL); coloured areas highlight the interpretation of lipid origin (based on Ficken et al., 2000) and $\delta$ D values with palaeoclimate interpretations versus depth. The desert biome record from Fig. 8 is repeated for comparison. 
dance in aquatic macrophytes (Cranwell, 1984; Ficken et al., 2000). The discontinuous GN200 biomarker record reveals several intervals where glacial-to-interglacial changes are preserved: between 217 to $210 \mathrm{~m}$ a change from glacial to interglacial conditions and between 165 to $148 \mathrm{~m}$ a cycle from interglacial to glacial and back to interglacial conditions. Samples further upcore suggest both glacial (128, $44 \mathrm{~m})$ and interglacial $(64,46 \mathrm{~m})$ conditions. GN200 $\delta \mathrm{D}$ values range between $-145 \%$ (interglacial) and $-190 \%$ o (glacial). Considering that the Ejina Basin is located in the mid-latitudes of the Northern Hemisphere and exhibits strong seasonal temperature variability, we interpret leaf-wax $\delta$ D values in GN200 as primarily a measure of temperature and indicative of the origin of moisture following interpretations given in Koutsodendris et al. (2018). As such, on glacial-interglacial timescales, more negative $\delta \mathrm{D}$ wax values should reflect colder rather than wetter conditions and/or a more distant water source. Koutsodendris et al. (2018) further propose that the $\delta \mathrm{D}$ value of $n \mathrm{C}_{29}$ and $n \mathrm{C}_{31}$ alkanes can be affected by evaporative deuterium enrichment of leaf water caused by enhanced evapotranspiration under low atmospheric humidity based on Sachse et al. (2006), Seki et al. (2011), and Rach et al. (2014). In this way, GN200 samples from dry glacials can be also affected by evapotranspiration.

The fossil pollen spectra composition resembles modern pollen spectra from the Alashan Plateau, collected from a landscape covered with shrubby desert vegetation consisting of Chenopodiaceae, Nitraria, and Ephedra species (Herzschuh et al., 2004). Discontinuous pollen data from 217-207 $\mathrm{m}$ indicate that shrub desert vegetation with predominance of Chenopodiaceae and Ephedra grew close to the coring site, and that mountain forests south of the coring site occupied a smaller area between 2.523 and $2.410 \mathrm{Ma}$. This correlates relatively well (within the error of the age model) with the long phase of low precipitation and tundra dominance in the Lake El'gygytgyn record from northeast Asia (Brigham-Grette et al., 2013; Tarasov et al., 2013). The fact that our pollen record does not reflect changes from glacial to interglacial conditions between 217 to $210 \mathrm{~m}$, as indicated by the biomarker record, may suggest that vegetation and pollen records from the arid region primarily mirror moisture conditions and not the temperature signal, as interpreted here for $\delta \mathrm{D}$. The observed changes in the pollen composition between $203-197 \mathrm{~m}$ (2.363 to $2.294 \mathrm{Ma}$ ) suggest a transition from an arid shrubby desert environment similar to the previous interval to a less arid one. The pollen composition indicates a further decrease in the climate aridity and spread of the temperate zone mountain forest in the upper reaches of the Heihe at $193 \mathrm{~m}(2.249 \mathrm{Ma})$ In the interval 168-160 m (1.954-1.857 Ma) higher pollen concentrations in the record are associated with a greater role for chenopods (known as very high pollen producers) in regional vegetation, indicating an increase in aridity (Herzschuh et al., 2004; Hou, 2001).
In contrast to a former chronology from drilling into the Ejina Basin (i.e. $230 \mathrm{~m}$ long core D100, Wünnemann et al., 2007a), where a palaeomagnetic dataset has been interpreted to encompass $250 \mathrm{ka}$, the playa-lake environment is now interpreted to extend further back in time. The onset of more humid conditions with lake sedimentation must date back to the early Pleistocene ( $>2 \mathrm{Ma}$ ) based on the Brunhes/Matuyama chron boundary at $60 \mathrm{~m}$ core depth and the occurrence of the Jaramillo and Olduvai sub-chrons interpreted in this study (Figs. 3 and 4). A further linear extrapolation of the time axis down to the core bottom is based on the following assumptions: (i) the Gauss chron (normal polarity) is not detected in the record; thus, GN200 reaches the onset of the Matuyama chron at maximum (2.59 Ma). Between 222.6 and $223.7 \mathrm{~m}$ a reversal to normal (Gauss?) is indicated but statistically not significant. But the extrapolated value comes close to the assumed value from linear extrapolation. (ii) The depositional sequence does not change prominently; the core portion between $222.6-172.0 \mathrm{~m}$ has an alternation of fluvial-alluvial layers intercalating with playa-lacustrine sediments typical for desert environments. In this sense, the two upper radionuclide ages (>2 Ma) are reversals (Fig. 4), which can be explained by reworking of old material that has been eroded and transported from the catchment prior to its final deposition in the Ejina Basin. In contrast, the lower sample age at $53.1 \mathrm{~m}$ depth $(0.84 \pm 0.12 \mathrm{Ma})$ is accepted as supporting the palaeomagnetic depth-to-age distribution because of its approximate overlap with it. (iii) Unit A sediments (222.6-217.0 m) are interpreted to be reworked material from the underlying Red Clay formation implying that the Neogene likely is close below the core bottom. (iv) Possibly there is a hiatus between the lowermost layers (223.7$222.6 \mathrm{~m})$ and the overlying sediments $(<222.6 \mathrm{~m})$; the core bottom (223.7-222.6 m) consists of fanglomerate sediments and red-coloured medium sandy sediments that are interpreted to represent the Red Clay formation, whereas sediments above a sharp boundary at $222.6 \mathrm{~m}$ turn into greycoloured fine sand to silt layers. The transition from an oxic to an anoxic environment is distinct.

The resulting linear depth-to-age relationship suggests that on a Quaternary timescale the overall sedimentation rates in the Ejina Basin are fairly constant. This matches results from Willenbring and von Blanckenburg (2010), who show that during the Late Cenozoic global erosion rates and weathering are stable; thus demonstrating that erosion and accumulation rates are balanced on mega-annum timescales. Even though at smaller scales one may distinguish between independent histories at the subcontinental and basin scales, our age model accepts that extrusion and crustal shortening are complementary processes that have been successively dominant throughout the India-Eurasia collision history (Métivier et al., 1999). This is thought to also affect the Ejina Basin sediment history, which receives detritus from the Qilian Shan in the northern Tibetan upland. On long timescales (Ma) the sedimentation rates in the Ejina Basin are low, i.e. 
$9 \mathrm{~cm} \mathrm{kyr}^{-1}$. For comparison, the Tarim and Qaidam basins in the Tibetan upland received $1 \mathrm{~m} \mathrm{kyr}^{-1}$ during the last $2.0 \mathrm{Ma}$ (Métivier et al., 1999).

Other results from surface dating using radionuclides show that the Gobi Desert in the northern margin of the basin developed $420 \mathrm{ka}$ ago, whereas the surfaces that developed from alluvial plains in the Heihe drainage basin formed during the last $190 \mathrm{ka}$ (Lü et al., 2010). The latter developed gradually northward and eastward to the terminal (palaeo)lakes of the river. These temporal and spatial variations in the Gobi Desert are likely a consequence of alluvial processes influenced by Tibetan Plateau uplift and tectonic activities within the Ejina Basin. This largely overlaps with results from Hetzel et al. (2002), who inferred Qilian Shan strike-slip movements from a series of incised terraces dating back to 40 to $170 \mathrm{ka}$ using cosmogenic nuclide dating. In addition, Li et al. (1999) suggest that tectonic activity was more intense around $160 \mathrm{ka}$ and $40 \mathrm{ka}$ based on ${ }^{14} \mathrm{C}$ and TL (thermoluminescence) dates from dissected alluvial fans in the Hexi Corridor. The relationship between tectonics, surface processes, and superimposed climate fluctuations are thus reasonable for at least the past $200 \mathrm{ka}$. Lü et al. (2010) put forward that possible episodes of Gobi Desert development within the last $420 \mathrm{ka}$ indicate that the advance/retreat of Qilian Shan glaciers during glacial-interglacial cycles might have been the dominant factor influencing the alluvial intensity and water volume in the basin. Intense floods and large water volumes would mainly occur during the short deglacial periods.

Thus, sedimentologic interpretations of core GN200 have regional palaeoclimatic and palaeotectonic implications. The presence of lacustrine and playa-lacustrine deposits in the Ejina Basin supports previous interpretations of semi-arid or arid climatic conditions, including indicators such as evaporitic (i.e. sulfur) and possibly greigite-bearing deposits in the NW Gobi Desert during the Pleistocene. This climatic interpretation extends previous interpretations to stretch back over a longer time window into the early-to-mid Pleistocene. Former studies presented sediment archives from desert and lake sediments in the area only until MIS 3 (e.g. Hartmann and Wünnemann, 2009; Hartmann et al., 2011), MIS 5 (Li et al., 2018a) or until $250 \mathrm{ka}$ (core D100; Wünnemann et al., 2007a).

Our pollen data discontinuously covering the core interval between 217 and $160 \mathrm{~m}$ (Fig. 9) suggests that the driest phases of the entire record occurred ca. 2.523-2.410 and 2.363-2.338 Ma; the wettest conditions took place ca. 2.3172.294 and $2.249 \mathrm{Ma}$; and the phase with intermediate, although unstable, conditions occurred between 1.953 and $1.857 \mathrm{Ma}$. This is in line with the biome reconstruction, which demonstrates highest scores for the desert biome during the driest (11.6-14.6) and lowest during the wettest (5.79.5) phases (Fig. 9). In comparison, the affinity score estimates of the desert biome calculated for the Holocene pollen record from Juyanze palaeolake (Herzschuh et al., 2004) vary between 15 and 19, which indicates an increased role of desert vegetation communities (and greater aridity) during the Holocene interval. A further comparison with the multiproxy records from Lake El'gygytgyn (Melles et al., 2012; Brigham-Grette et al., 2013) indicates that the reconstructed wet and dry phases in the middle and northern latitudes of East Asia can be broadly synchronous. However, neither the accuracy of the GN200 age model nor the resolution of the presented pollen record here allows for more precise conclusions. The same is true when interpreting the $n$-alkane record. When comparing the $n$-alkanes with the desert biome record (Fig. 9), the warm phases indicated by higher $\delta \mathrm{D}$ values (at depths between 217 to $210 \mathrm{~m}$ and between 165 to $160 \mathrm{~m}$ ) tend to be mirrored by drier desert biomes.

What effect, if any, did tectonic pulses along the Hexi Corridor to Heli Shan boundary fault have on sedimentation trends in the Ejina Basin? Predictably, tectonic uplift in the source area, i.e. the Qilian Shan (Zheng et al., 2017), should generate periods of regression and/or coarse clastic influx in the adjacent basin, i.e. the Hexi Corridor. It is beyond the scope of this paper to discuss this problem further but perhaps the cores extracted from the Hexi Corridor (DWJ, XKJD) presented by Pan et al. (2016) act as a support for the possibility of tectonic control on sedimentation in the Ejina Basin. The authors concluded that the Heli Shan opening occurred around 1.1 Ma and allowed the Heihe to flow northward into the Ejina Basin (Fig. 11 of Pan et al., 2016; therein). The geomorphological change in catchment size, presumably triggered by block movement and/or uplift, would then provide a tipping element that finally led to the expulsion of the distal lake environment in favour of an extensive alluvial fan environment. Alluvial fan progradation may be flanked by changing evaporation rates and humidity changes on glacial-to-interglacial timescales though.

In this sense, the chronology of the GN200 is confirmed by findings by Pan et al. (2016) and their cores from the Heihe fluvial-alluvial plains in the Hexi Corridor. Thus, the megasequence forming unit $\mathrm{C}$ in GN200 is a coarsening up succession that represents the arrival and progradation of the Heihe alluvial fan in the Ejina Basin. An upcore enhanced chlorite load, which to some extent is paralleled by an enhanced dolomite load in units B and C, may support this interpretation; chlorite is known to be exposed in basaltic bedrock outcropping in the Qilian Shan and so is dolomite; both minerals are interpreted to be indicative provenance minerals of the southern catchment (Song et al., 2009; Schimpf, 2019), which increase in the Ejina Basin with the arrival of Heihe river sediments.

Pan et al. (2016) discussed a previous study, which suggested that the Shiyang River ( $400 \mathrm{~km}$ SE from Heihe) formed approximately 1.2 Ma (Pan et al., 2007), based on studies of the highest fluvial terraces. This age is consistent with the formation age of the Tengger Desert (Li et al., 2014). A recent study in the Badain Jaran Desert (Wang et al., 2015) suggested a formation age of at least $\sim 1.1$ Ma based on elec- 


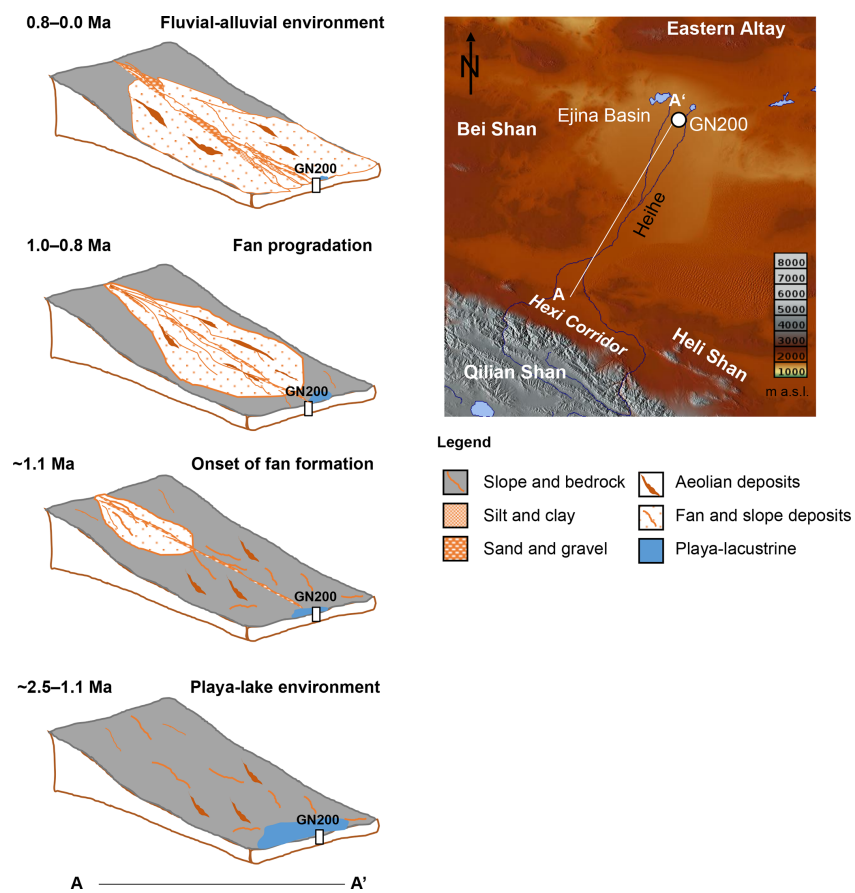

Figure 10. Conceptual model illustrating the progradation of the Heihe alluvial fan into the Ejina Basin. (Service layer credits: SRTM under CC BY-SA.)

tron spin resonance (ESR) dating of aeolian sands from a $310 \mathrm{~m}$ drilling core. New dating of the Ejina Basin sediment fill as recovered in GN200 brings additional input into the debate on the timing of when this part of the Gobi Desert started to serve as a sediment source for downwind sediment accumulation such as in the Badain Jaran Desert and Tengger Desert and ultimately the Chinese Loess Plateau (Chen et al., 2006). The onset of the Ejina alluvial fan formation coincides with increased sedimentation rates on the Chinese Loess Plateau < $1 \mathrm{Ma}$ (Sun and An, 2005; Sun et al., 2010), suggesting that the Heihe sediment fan formation may have served as a prominent upwind sediment source to it. The prevailing westerly jet stream, which is responsible for much of the wind energy in the area, is interpreted to react on strong summer insolation and it has been found out that a changing position and orientation of it can be reconstructed at least for Holocene climate fluctuations based on pollen records from China and Mongolia (Herzschuh et al., 2019). However, a Pleistocene wind pattern reconstruction remains open by now. Figure 10 summarizes a depositional model of a progressively northward propagation of the Heihe alluvial fan environment into the Ejina Basin.

The arrival of Heihe sediments coincides with the climate transition during the Mid-Pleistocene. Koutsodendris et al. (2018) discuss that this time, the Mid-Pleistocene Transition (MPT; 1250-750 ka), is characterized by a change in global climate dynamics associated with the expansion of polar ice sheets (see also Head and Gibbard, 2015; Clark et al.,
2006; Raymo et al., 2006). Koutsodendris et al. (2018, and references used therein) discuss further that as a consequence of global cooling during the MPT glaciers formed in highelevation settings in the low and middle latitudes of both hemispheres. Glacial-interglacial contrasts strengthened after $1200 \mathrm{ka}$ according to Diekmann and Kuhn (2002) based on analysing bulk parameters of a marine sediment core from the southeastern South Atlantic.

Terrestrial records in Central Asia mirror MPT cooling (Zhisheng et al., 2011; Prokopenko et al., 2006; Sun et al., 2010) and temperature and ice volume change during glacials and interglacials as reviewed in Koutsodendris et al. (2018). For example, core SG-1 from the Qaidam Basin has a record of pollen concentration, $\mathrm{CaCO}_{3}$ content, and magnetic susceptibility that closely tracks global ice volume (Lisiecki and Raymo, 2005) and monsoonal activity in Central Asia (Zhisheng et al., 2011; Sun et al., 2010) on glacial-interglacial timescales according to Koutsodendris et al. (2018). It has been concluded from a previous sediment core that the Tibetan Plateau may have been glaciated at least to some extent during the MPT based on palynological and $\delta \mathrm{D}$ wax-based palaeohydrological data analysis (Koutsodendris et al., 2018). From the same Qaidam Basin record (SG-1) other sediment properties show clear glacial-interglacial humidity changes across the MPT based on magnetic and palynological proxy data (Herb et al., 2013, 2015). Even though GN200 covers the same age range the discontinuous proxy record in concert with the unknown succession of accumulation and erosion hampers a detailed analysis comparable to the palaeolake sediments from the Qaidam Basin. In addition, it is not yet clear whether GN200 lipid biomarkers have been transported by wind from remote areas or by fluvial input from the catchment or as a mixture of both.

\section{Conclusions}

A $223 \mathrm{~m}$ long core (GN200) was drilled in the central part of the Ejina Basin. Multiple parameter analysis of sediment properties illustrates that the basin is filled primarily with playa-lacustrine deposits in the lower half and holds a transition to an increasing frequency of fluvial-alluvial layers in the upper half. The lake environment shrank northeastwards when in the southwestern part fluvial-alluvial deposits accumulated in a large sediment fan. The Quaternary playalacustrine to fluvial-alluvial deposition is presumably separated by a hiatus from the Neogene-Upper Cretaceous-aged Red Clay formation, which is encountered in the bottom $6 \mathrm{~m}$ of the core.

The tipping element that induced the transformation from an early-to-mid Pleistocene more humid and playadominated environment to a more arid environment dominated by an alluvial fan deposition is likely triggered by uplift and tectonic activity in the upper reaches of the Heihe. This environmental framework is in accordance with the re- 
gional environmental background inferred from other studies. It suggests that the contribution of dust from the Ejina Basin to the Chinese Loess Plateau was relatively limited during the early Quaternary, but it may have increased after the progradation of the sediment fan into the basin after about $<1$ Ma. 


\section{Appendix A}

(a)

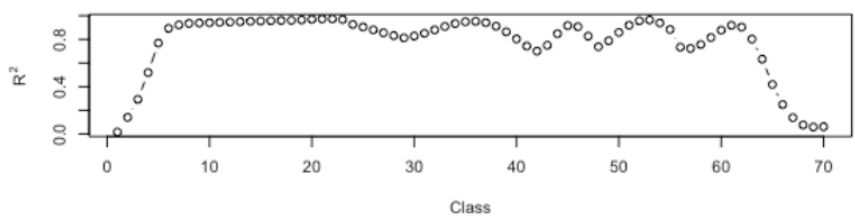

(c)

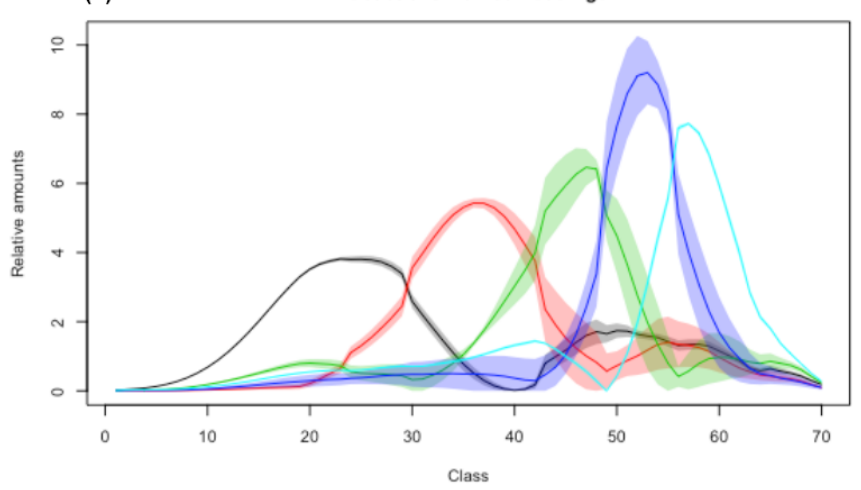

(b)

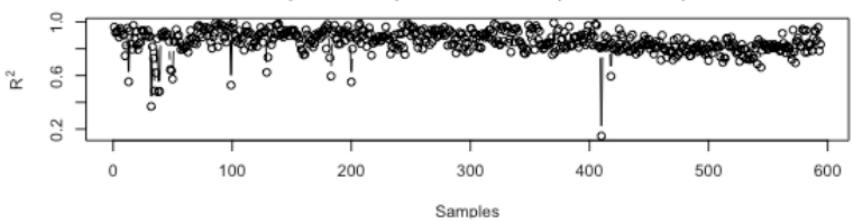

(d)

Robust endmember scores

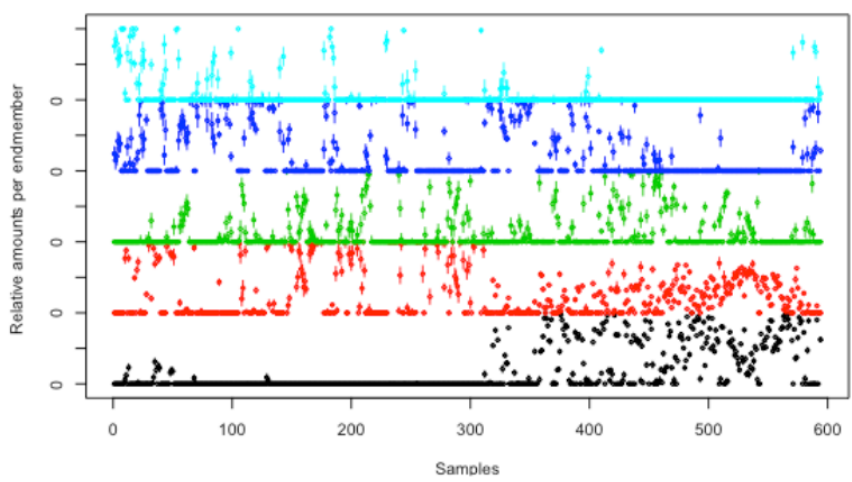

Endmember ID (mode position | explained variance)

$-\operatorname{EM} 1(26 \mid 19 \%) \quad-\operatorname{EM} 2(36 \mid 27 \%) \quad \operatorname{EM}(48 \mid 11 \%) \quad-\operatorname{EM}(52 \mid 34 \%)$ EM5 $(57 \mid 8.6 \%)$

Figure A1. Default graphical output of robust $\operatorname{EM}()$ as part of the compact protocol, including class- and sample-wise explained variances (a) and mean robust loadings as line graphs, mean robust scores as panels of points (b). Polygons around loadings and bars around scores represent 1 standard deviation. A legend with main mode position and explained variance of each endmember. Classes span from 0.19 to $1784 \mu \mathrm{m}$. For further reading see Dietze and Dietze (2019). 
Data availability. The datasets are available on PANGEA https://doi.org/10.1594/PANGAEA.906582 (Schwamborn et al., 2019).

Author contributions. GS carried out the sediment sampling and measured various sediment properties. GS also prepared the article with input from all co-authors. KH, BW, and BD designed the study. WR carried out the magnetic measurements. AWR carried out the fossil counting and interpretation, MS and FK conducted the pollen analysis, PET wrote the pollen-related text, and MAB was in charge of the lipid biomarker measuring program.

Competing interests. The authors declare that they have no conflict of interest.

Acknowledgements. Todd Ehlers, Mirijam Schaller, Jessica Starke, Alexander Koutsodendris, and Elisabeth Dietze are thanked for helping at various stages of the study. Thanks to the Notre Dame Center for Environmental Science and Technology and Dana Biasatti, Keith O'Connor, and Alejandra Cartagena Sierra for assistance in the lab. Three reviewers are thanked for helping us to improve the text.

Financial support. This research has been supported by the BMBF (grant nos. 03G0863D, 03G0863E).

Review statement. This paper was edited by Marc Oliva and reviewed by Mark Allen, Attila Ciner, and one anonymous referee.

\section{References}

Aitchison, J.: Relative variation diagrams for describing patterns of compositional variability, Math. Geol., 22, 487-511, https://doi.org/10.1007/BF00890330, 1990.

Allen, M. B., Walters, R. J., Song, S., Saville, C., De Paola, N., Ford, J., Hu, Z., and Sun, W.: Partitioning of oblique convergence coupled to the fault locking behavior of fold-and-thrust belts: Evidence from the Qilian Shan, northeastern Tibetan Plateau, Tectonics, 36, 1679-1698, https://doi.org/10.1002/2017TC004476, 2017.

Balco, G. and Rovey II, C. W.: Isochron method for cosmogenicnuclide dating of buried soils and sediments, Am. J. Sci., 308, 1083-1114, https://doi.org/10.2475/10.2008.02, 2008.

Becken, M., Hölz, S., Fiedler-Volmer, R., Hartmann, K., Wünnemann, B., and Burkhardt, H.: Electrical resistivity image of the Jingsutu Graben at the NE margin of the Ejina Basin (NW China) and implications for the basin development, Geophys. Res. Lett., 34, L09315, https://doi.org/10.1029/2007GL029412, 2007.

Blair, T. C. and McPherson, J. G.: Alluvial fan processes and forms, in: Geomorphology of desert environments, edited by: Abrahams, A. A. and Parsons, A. J., Springer, Dordrecht, 354-402, 1994.
Borchers, B., Marrero, S., Balco, G., Caffee, M., Goehring, B., Lifton, N., Nishiizumi, K., Phillips, F., Schaefer, J., and Stone, J.: Geological calibration of spallation production rates in the CRONUS-Earth project, Quat. Geochronol., 31, 188-198, https://doi.org/10.1016/j.quageo.2015.01.009, 2016.

Braucher, R., Merchel, S., Borgomano, J., and Bourlès, D. L.: Production of cosmogenic radionuclides at great depth: A multi element approach, Earth Planet. Sc. Lett., 309, 1-9, https://doi.org/10.1016/j.epsl.2011.06.036, 2011.

Brigham-Grette, J., Melles, M., Minyuk, P., Andreev, A., Tarasov, P., DeConto, R., Koenig, S., Nowaczyk, N., Wennrich, V., Rosén, P., Haltia-Hovi, E., Cook, T., Gebhardt, C., Meyer-Jacob, C., Snyder, J., and Herzschuh, U.: Pliocene Warmth, Polar Amplification, and Stepped Pleistocene Cooling recorded in NE Arctic Russia, Science, 340, 1421-1427, 2013.

Chadima, M. and Hrouda, F.: Remasoft 3.0 a user-friendly paleomagnetic data browser and analyzer, Travaux Géophysiques, 27, 20-21, 2006.

Che, X. and Li, G.: Binary sources of loess on the Chinese Loess Plateau revealed by U-Pb ages of zircon, Quaternary Res., 80, 545-551, 2013.

Chen, F. H., Yu, Z. C., Yang, M. L., Ito, E., Wang, S. M., Madsen, D. B., Huang, X. Z., Zhao, Y., Sato, T., Birks, H. J. B., Bommer, I., Chen, J. H., An, C. B., and Wünnemann, B.: Holocene moisture evolution in arid central Asia and its out-of phase relationship with Asian monsoon history, Quaternary Sci. Rev., 27, 351-364, 2008.

Chmeleff, J., von Blanckenburg, F., Kossert, K., and Jakob, D.: Determination of the ${ }^{10} \mathrm{Be}$ half-life by multicollector ICP-MS and liquid scintillation counting, Nucl. Instrum. Meth. B, 268, 192199, https://doi.org/10.1016/j.nimb.2009.09.012, 2010.

Clark, P. U., Archer, D., Pollard, D., Blum, J. D., Rial, J. A., Brovkin, V., Mix, A. C., Pisias, N. G., and Roy, M.: The middle Pleistocene transition: Characteristics, mechanisms, and implications for long-term changes in atmospheric $p \mathrm{CO}_{2}$, Quaternary Sci. Rev., 25, 3150-3184, https://doi.org/10.1016/j.quascirev.2006.07.008, 2006.

Cohen, K. M. and Gibbard, P. L.: Global chronostratigraphical correlation table for the last 2.7 million years, version 2019 QI-500, Quatern. Int., 500, 20-31, 2019.

Cranwell, P. A.: Lipid geochemistry of sediments from Upton Broad, a small productive lake, Org. Geochem., 7, 25-37, 1984.

Cunningham, W. D., Windley, B. F., Dorjnamjaa, D., Badamgarov, J., and Saandar, M.: Late Cenozoic transpression in southwestern Mongolia and the Gobi Altai-Tien Shan connection, Earth Planet. Sc. Lett., 140, 67-81, 1996.

Derbyshire, E., Meng, X. M., and Kemp, R. A.: Provenance, transport and characteristics of modern aeolian dust in western Gansu Province, China, and interpretation of the Quaternary loess record, J. Arid Environ., 39, 497-516, 1998.

Diekmann, B. and Kuhn, G.: Sedimentary record of the midPleistocene climate transition in the southeastern South Atlantic (ODP Site 1090), Palaeogeogr. Palaeocl., 182, 241-258, 2002.

Dietze, E. and Dietze, M.: Grain-size distribution unmixing using the R package EMMAgeo, E\&G Quaternary Sci. J., 68, 29-46, https://doi.org/10.5194/egqsj-68-29-2019, 2019.

Dietze, E., Hartmann, K., Diekmann, B., Ijmker, J., Lehmkuhl, F., Opitz, S., Stauch, G., Wünnemann, B., and Borchers, A.: An end-member algorithm for deciphering modern detri- 
tal processes from lake sediments of Lake Donggi Cona, NE Tibetan Plateau, China, Sediment. Geol., 243/244, 169-180, https://doi.org/10.1016/j.sedgeo.2011.09.014, 2012.

Dill, H. G.: Residual clay deposits on basement rocks: The impact of climate and the geological setting on supergene argillitization in the Bohemian Massif (Central Europe) and across the globe, Earth-Sci. Rev., 165, 1-58, 2017.

Domrös, M. and Peng, G.: The Climate of China, Chap. 5.7, Springer, https://doi.org/10.1007/978-3-642-73333-8, 2008.

Eglinton, G. and Hamilton, R. J.: Leaf epicuticular waxes, Science, 156, 3780, 1322-1335, 1967

Ficken, K. J., Li, B., Swain, D. L., and Eglinton, G.: An n-alkane proxy for the sedimentary input of submerged/floating freshwater aquatic macrophytes, Org. Geochem., 31, 745-749, 2000.

Gat, J. R.: Oxygen and hydrogen isotopes in the hydrological cycle, Annu. Rev. Earth Pl. Sc., 24, 225-262, https://doi.org/10.1146/annurev.earth.24.1.225, 1996.

Gingele, F. X., De Deckker, P., and Hillenbrand, C. D.: Clay mineral distribution in surface sediments between Indonesia and NW Australia - source and transport by ocean currents, Mar. Geol., 179, 135-146, 2001.

Granger, D. E.: Cosmogenic Nuclide Burial Dating in Archaeology and Paleoanthropology, Treatise on Geochemistry, 14, 8197, 2014.

Grimm, E. C.: Tilia 1.7.16 Software. Springfield, IL: Illinois State Museum, Research and Collection Center, 2011.

Gunin, P. D., Vostokova, E. A., Dorofeyuk, N. I., Tarasov, P. E., and Black, C. C.: Vegetation dynamics of Mongolia, Geobotany 26, Kluwer Academic Publishers, Dordrecht, 238 pp., 1999.

Guo, Z. T., Ruddiman, W. F., Hao, Q. Z., Wu, H. B., Qiao, Y. S., Zhu, R. X., Peng, S. Z., Wei, J. J., Yuan, B. Y., and Liu, T. S.: Onset of Asian desertification by $22 \mathrm{Myr}$ ago inferred from loess deposits in China, Nature, 416, 159-163, 2002.

Hartmann, K. and Wünnemann, B.: Hydrological changes and Holocene climate variations in NW China, inferred from lake sediments of Juyanze palaeolake by factor analyses, Quatern. Int., 194, 28-44, 2009.

Hartmann, K., Wünnemann, B., Hölz, S., Krätschell, A., and Zhang, H. C.: Neotectonic constraints on Ejina inland basin in northcentral China, derived from remote sensing, geomorphology and geophysical analyses, in: Growth and Collapse of the Tibetan Plateau, edited by: Gloaguen, R. and Ratschbacher, L., Geol. Soc. Lond. Special Publ., 353, 221-233, 2011.

Head, M. J. and Gibbard, P. L.: Early-Middle Pleistocene transitions: Linking terrestrial and marine realms, Quatern. Int., 389, 7-46, https://doi.org/10.1016/j.quaint.2015.09.042, 2015.

Herb, C., Zhang, W., Koutsodendris, A., Appel, E., Fang, X., and Pross, J.: Environmental implications of the magnetic record in Pleistocene lacustrine sediments of the Qaidam Basin, NE Tibetan Plateau, Quatern. Int., 313, 218-229, 2013.

Herb, C., Koutsodendris, A., Zhang, W., Appel, E., Fang, X., Voigt, S., and Pross, J.: Late Plio-Pleistocene humidity fluctuations in the western Qaidam Basin (NE Tibetan Plateau) revealed by an integrated magnetic - palynological record from lacustrine sediments, Quaternary Res., 84, 457-466, 2015.

Herzschuh, U., Tarasov, P., Wünnemann, B., and Hartmann, K.: Holocene vegetation and climate of the Alashan Plateau, NW China, reconstructed from pollen data, Palaeogeogr. Palaeocl., 211, 1-17, 2004.
Herzschuh, U., Cao, X., Laepple, T., Dallmeyer, A., Telford, R. J., Ni, J., Chen, F., Kong, Z., Guangxiu, L., Liu, K.-B., Liu, X., Stebich, M., Tang, L., Tian, F., Wang, Y., Wischnewski, J., Xu, Q., Yan, S., Yang, Z., Yu., G., Zhang, Y., Zhao, Y., and Zheng, Z.: Position and orientation of the westerly jet determined Holocene rainfall patterns in China, Nat. Commun., 10, 1-8, https://doi.org/10.1038/s41467-019-09866-8, 2019.

Hetzel, R., Niedermann, S., Tao, M., Kubik, P. W., Ivy-Ochs, S., Gao, B., and Strecker, M. R.: Low slip rates and long-term preservation of geomorphic features in Central Asia, Nature, 417, 428-432, 2002.

Hillier, S.: Erosion, sedimentation, and sedimentary origin of clays, in: Clays and the environment, edited by: Velde, B., Springer Verlag, Berlin, 162-219, 1995.

Hillier, S.: Quantitative analysis of clay and other minerals in sandstones by X-ray powder diffraction (XRPD), Int. Assoc. Sediment. Spec. Publ., 34, 213-251, 2003.

Hölz, S., Polag, D., Becken, M., Fiedler-Volmer, R., Zhang, H. C., Hartmann, K., and Burkhardt, H.: Electromagnetic and geoelectric investigation of the Gurinai structure, Inner Mongolia, NW China, Tectonophysics, 445, 26-48, 2007.

Hou, H.: Vegetation atlas of China, Science Press China, Beijing, 113-124, 2001.

Hou, J., D'Andrea, W. J., and Huang, Y.: Can sedimentary leaf waxes record $\mathrm{D} / \mathrm{H}$ ratios of continental precipitation? Field, model, and experimental assessments, Geochim. Cosmochim. Ac., 72, 3503-3517, 2008.

$\mathrm{Hu}, \mathrm{F}$. and Yang, X.: Geochemical and geomorphological evidence for the provenance of aeolian deposits in the Badain Jaran Desert, northwestern China, Quaternary Sci. Rev., 131, 179-192, 2016.

Jeong, G. Y.: Bulk and single-particle mineralogy of Asian dust and a comparison with its source soils, J. Geophys. Res., 113, D02208, https://doi.org/10.1029/2007JD008606, 2008.

Kirschvink, J. L.: The least-squares line and plane and the analysis of palaeomagnetic data, Geophys. J. Int., 62, 699-718, 1980.

Korschinek, G., Bergmaier, A., Faestermann, T., Gerstmann, U. C., Knie, K., Rugel, G., Wallner, A., Dillmann, I., Dollinger, G., von Gostomski, C. L., Kossert, K., Maiti, M., Poutivtsev, M., and Remmert, A.: A new value for the half-life of ${ }^{10} \mathrm{Be}$ by Heavy-Ion Elastic Recoil Detection and liquid scintillation counting, Nucl. Instrum. Meth. B, 268, 187-191, https://doi.org/10.1016/j.nimb.2009.09.020, 2010.

Koutsodendris, A., Sachse, D., Appel, E., Herb, C., Fischer, T., Fang, X., and Pross, J.: Prolonged monsoonal moisture availability preconditioned glaciation of the Tibetan Plateau during the Mid-Pleistocene Transition, Geophys. Res. Lett., 45, 13020 13030, https://doi.org/10.1029/2018GL079303, 2018.

Leipe, C., Kobe, F., and Müller, S.: Testing the performance of sodium polytungstate and lithium heteropolytungstate as nontoxic dense media for pollen extraction from lake and peat sediment samples, Quatern. Int., 516, 207-214, 2019.

Li, G., Pettke, T., and Chen, J.: Increasing Nd isotopic ratio of Asian dust indicates progressive uplift of the north Tibetan Plateau since the middle Miocene, Geology, 39, 199-202, 2011.

Li, G., She, L., Jin, M., Yang, H., Madsen, D., Chun, X., and Chen, F.: The spatial extent of the East Asian summer monsoon in arid NW China during the Holocene and Last Interglaciation, Glob. Planet. Change, 169, 48-65, https://doi.org/10.1016/j.gloplacha.2018.07.008, 2018a. 
Li, G., Madsen, D. B., Jin, M., Stevens, T., Tao, S., She, L., Yang, L., Li, F, Wei, H., Duan, Y., and Chen, F.: Orbital scale lake evolution in the Ejina Basin, central Gobi Desert, China revealed by K-feldspar luminescence dating of paleolake shoreline features, Quatern. Int., 482, 109-121, 2018b.

Li, X., Cheng, G., Ge, Y., Li, H., Han, F., Hu, X., and Cai, X.: Hydrological cycle in the Heihe River Basin and its implication for water resource management in endorheic basins, J. Geophys. Res.-Atmos., 123, 890-914, https://doi.org/10.1002/2017JD027889, 2018.

Li, Y., Yang, J., Tan, L., and Duan, F.: Impact of tectonics on alluvial landforms in the Hexi Corridor, Northwest China, Geomorphology, 28, 299-308, 1999.

Li, Z., Sun, D., Chen, F., Wang, F., Zhang, Y., Guo, F., Wang, X., and $\mathrm{Li}, \mathrm{B}$.: Chronology and paleoenvironmental records of a drill core in the central Tengger Desert of China, Quaternary Sci. Rev., 85, 85-98, 2014.

Lifton, N., Sato, T., and Dunai, T. J.: Scaling in situ cosmogenic nuclide production rates using analytical approximations to atmospheric cosmic-ray fluxes, Earth Planet. Sc. Lett., 386, 149-160, https://doi.org/10.1016/j.eps1.2013.10.052, 2014.

Liu, X., Yu, J., Wang, P., Zhang, Y., and Du, C.: Lake evaporation in a hyper-arid environment, Northwest of China - measurement and estimation, Water, 8, 21 pp., https://doi.org/10.3390/w8110527, 2016.

Long, H. and Shen, J.: Underestimated ${ }^{14}$ C-based chronology of late Pleistocene high lake-level events over the Tibetan Plateau and adjacent areas: Evidence from the Qaidam Basin and Tengger Desert, Sci. China Earth Sci., 58, 183-194, https://doi.org/10.1007/s11430-014-4993-2, 2015.

Lü, Y., Gu, Z., Aldahan, A., Zhang, H., Possnert, G., and Lei, G.: ${ }^{10} \mathrm{Be}$ in quartz gravel from the Gobi Desert and evolutionary history of alluvial sedimentation in the Ejina Basin, Inner Mongolia, China, Chinese Sci. Bull., 55, 3802-3809, 2010.

Marrero, S. M., Phillips, F. M., Borchers, B., Lifton, N., Aumer, R., and Balco, G.: Cosmogenic nuclide systematics and the CRONUScalc program, Quat. Geochronol., 31, 160-187, https://doi.org/10.1016/j.quageo.2015.09.005, 2016.

Melles, M., Brigham-Grette, J., Minyuk, P. S., Nowaczyk, N. R., Wennrich, V., DeConto, R. M., Anderson, P. M., Andreev, A. A., Coletti, A., Cook, T. L., Haltia-Hovi, E., Kukkonen, M., Lozhkin, A. V., Rosén, P., Tarasov, P., Vogel, H., and Wagner, B.: 2.8 Million years of Arctic climate change from Lake El'gygytgyn, NE Russia, Science, 337, 315-320, 2012.

Métivier, F., Gaudemer, Y., Tapponnier, P., and Klein, M.: Mass accumulation rates in Asia during the Cenozoic, Geophys. J. Int., 137, 280-318, 1999.

Mischke, S.: Mid and Late Holocene palaeoenvironment of the lakes Eastern Juyanze and Sogo Nur in NW China, based on ostracod species assemblages and shell chemistry, Berliner Geowiss. Abh., E35, 131 pp., 2001.

Mölg, T., Maussion, F., and Scherer, D.: Mid-Latitude Westerlies as a Driver of Glacier Variability in Monsoonal High Asia, Nat. Clim. Change, 4, 68-73, https://doi.org/10.1038/nclimate2055, 2014.

Nishiizumi, K.: Preparation of ${ }^{26} \mathrm{Al}$ AMS standards, Nucl. Inst. Meth. B, 223/224, 388-392, 2004.
Nishiizumi, K., Imamura, M., Caffee, M. W., Southon, J. R., Finkel, R. C., and McAninch, J.: Absolute calibration of ${ }^{10} \mathrm{Be}$ AMS standards, Nucl. Inst. Meth. B, 258, 403-413, 2007.

Norris, T. L., Gancarz, A. J., Rokop, D. J., and Thomas, K. W.: Half-life of 26Al, Lunar Planet. Sci. Conf., J. Geophys. Res., 88, B331, https://doi.org/10.1029/JB088iS01p0B331, 1983.

Pan, B., Chen, D., Hu, X., Cao, X., Chen, J., and Mao, J.: Drainage evolution of the Heihe River in western Hexi Corridor, China, derived from sedimentary and magnetostratigraphic results, Quaternary Sci. Rev., 150, 250-263, 2016.

Pang, J., Yu, J., Zheng, D., Wang, W., Ma, Y., Wang, Y., and Wang, Y.: Neogene expansion of the Qilian Shan, north Tibet: Implications for the dynamic evolution of the Tibetan Plateau, Tectonics, 38, 1018-1032, https://doi.org/10.1029/2018TC005258, 2019.

Petschick, R., Kuhn, G., and Gingele, F.: Clay mineral distribution in surface sediments of the South Atlantic: sources, transport, and relation to oceanography, Mar. Geol., 130, 203-229, 1996.

Porter, S. C.: Loess records/China, edited by: Elias, S., The Encyclopedia of Quaternary Sciences, Elsevier, Amsterdam, 14291440, 2007.

Prentice, I. C., Guiot, J., Huntley, B., Jolly, D., and Cheddadi, R.: Reconstructing biomes from palaeoecological data: a general method and its application to European pollen data at 0 and $6 \mathrm{ka}$, Clim. Dynam., 12, 185-194, 1996.

Prokopenko, A. A., Hinnov, L. A., Williams, D. F., and Kuzmin, M. I.: Orbital forcing of continental climate during the Pleistocene: A complete astronomically tuned climatic record from Lake Baikal, SE Siberia, Quaternary Sci. Rev., 25, 3431-3457, https://doi.org/10.1016/j.quascirev.2006.10.002, 2006.

Rach, O., Brauer, A., Wilkes, H., and Sachse, D.: Delayed hydrological response to Greenland cooling at the onset of the Younger Dryas in western Europe, Nat. Geosci., 7, 109-112, 2014.

Raymo, M. E., Lisiecki, L. E., and Nisancioglu, K. H.: Plio-Pleistocene ice volume, Antarctic climate, and the global $\delta^{18} \mathrm{O}$ record, Science, 313, 492-495, https://doi.org/10.1126/science.1123296, 2006.

Rudersdorf, A., Hartmann, K., Yu, K., Stauch, G., and Reicherter, K.: Seismites as indicators for Holocene seismicity in the northeastern Ejina Basin, Inner Mongolia, Geol. Soc. Lond. Spec. Publ., 432, 213-231, 2017.

Sachse, D., Radke, J., and Gleixner, G.: Hydrogen isotope ratios of recent lacustrine sedimentary n-alkanes record modern climate variability, Geochim. Cosmochim. Ac., 68, 4877-4889, 2004.

Sachse, D., Billault, I., Bowen, G. J., Chikaraishi, Y., Dawson, T. E., Feakins, S. J., Freeman, K. H., Magill, C. R., McInerney, F. A., van der Meer, M. T. J., Polissar, P., Robins, R. J., Sachs, J. P., Schmidt, H.-L., Sessions, A. L., White, J. W. C., West, J. B., and Kahmen, A.: Molecular paleohydrology: Interpreting the hydrogen-isotopic composition of lipid biomarkers from photosynthesizing organisms, Annu. Rev. Earth Pl. Sc., 40, 221-249, https://doi.org/10.1146/annurev-earth-042711-105535, 2012.

Schaller, M., Ehlers, T. A., Stor, T., Torrent, J., Lobato, L., Christl, M., and Vockenhuber, C.: Timing of European fluvial terrace formation and incision rates constrained by cosmogenic nuclide dating, Earth Planet. Sc. Lett., 451, 221-231, 2016.

Schimpf, S.: Herkunft und Ablagerungsmilieu quartärer Sedimente im Einzugsgebiet des Heihe, NW China, (engl.: Sources and depositional environment of Quaternary sediments in the Heihe catchment, NW China), Dissertation submitted to the Faculty of 
Mathematics and Natural Sciences, University Potsdam, 195 pp., 2019 (in German).

Schwamborn, G., Hartmann, K., Wünnemann, B., Rösler, W., Wefer-Roehl, A., Pross, J., and Diekmann, B.: Sedimentology, geochemistry and mineralogy of sediment core GN200 from the Gaxun Nur basin (Ejina basin), NW China, PANGAEA, https://doi.org/10.1594/PANGAEA.906582, 2019.

Seki, O., Meyers, P. A., Yamamoto, S., Kawamura, K., Nakatsuka, T., Zhou, W., and Zheng, Y.: Plant-wax hydrogen isotopic evidence for postglacial variations in delivery of precipitation in the monsoon domain of China, Geology, 39, 875-878, 2011.

Singer, A.: The paleoclimatic interpretation of clay minerals in sediments - a review, Earth-Sci. Rev., 21, 251-293, 1984.

Singer, B. S.: A Quaternary geomagnetic instability time scale, Quat. Geochronol., 21, 29-52, 2014.

Song, S., Niu, Y., Zhang, L., Wei, C., Liou, J. G., and Su, L.: Tectonic evolution of early Paleozoic HP metamorphic rocks in the North Qilian Mountains, NW China: new perspectives, J. Asian Earth Sci., 35, 334-353, 2009.

Song, Y., Fang, X., Torii, M., Ishikawa, N., Li, J., and An, Z.: Late Neogene rock magnetic record of climatic variation from Chinese eolian sediments related to uplift of the Tibetan Plateau, J. Asian Earth Sci., 30, 324-332, 2007.

Stockmarr, J.: Tablets with spores used in absolute pollen analysis, Pollen et Spores, 13, 614-621, 1971.

Su, Q., Nie, J., Luo, Z., Li, M., Heermance, R., and Garzione, C.: Detection of strong precession cycles from the late Pliocene sedimentary records of northeastern Tibetan Plateau, Geochem. Geophy. Geosy., 20, 3901-3912, https://doi.org/10.1029/2019GC008447, 2019.

Sun, J.: Provenance of loess material and formation of loess deposits on the Chinese Loess Plateau, Earth Planet. Sc. Lett., 203, 845859,2002

Sun, Y. and An, Z.: Late Pliocene-Pleistocene changes in mass accumulation rates of eolian deposits on the central Chinese Loess Plateau, J. Geophys. Res.-Atmos., 110, D23101, https://doi.org/10.1029/2005JD006064, 2005.

Sun, Y., An, Z., Clemens, S. C., Bloemendal, J., and Vandenberghe, J.: Seven million years of wind and precipitation variability on the Chinese Loess Plateau, Earth Planet. Sc. Lett., 297, 525-535, https://doi.org/10.1016/j.epsl.2010.07.004, 2010.

Tarasov, P. E., Cheddadi, R., Guiot, J., Bottema, S., Peyron, O., Belmonte, J., Ruiz-Sanchez, V., Saadi, F. A., and Brewer, S.: A method to determine warm and cool steppe biomes from pollen data; application to the Mediterranean and Kazakhstan Regions, J. Quaternary Sci., 13, 335-344, 1998.

Tarasov, P. E., Andreev, A. A., Anderson, P. M., Lozhkin, A. V., Leipe, C., Haltia, E., Nowaczyk, N. R., Wennrich, V., BrighamGrette, J., and Melles, M.: A pollen-based biome reconstruction over the last 3.562 million years in the Far East Russian Arctic new insights into climate-vegetation relationships at the regional scale, Clim. Past, 9, 2759-2775, https://doi.org/10.5194/cp-92759-2013, 2013.

Tjallingii, R., Röhl, U., Kölling, M., and Bickert, T.: Influence of the water content on X-ray fluorescence core-scanning measurements in soft marine sediments, Geochem. Geophy. Geosy., 8, Q02004, https://doi.org/10.1029/2006GC001393, 2007.

van den Boogaart, K. G. and Tolosana-Delgado, R. (Eds.): Analyzing compositional data with R., Heidelberg-New York-Dodrecht-
London, Springer, 273 pp., https://doi.org/10.1007/978-3-64236809-7, 2013.

Verbrugge, L. N., Schipper, A. M., Huijbregts, M. A., Van der Velde, G., and Leuven, R. S.: Sensitivity of native and non-native mollusc species to changing river water temperature and salinity, Biol. Invasions, 14, 1187-1199, 2012.

Wang, F., Sun, D., Chen, F., Bloemendal, J., Guo, F., Li, Z., Zhang, Y., Li, B., and Wang, X.: Formation and evolution of the Badain Jaran Desert, North China, as revealed by a drill core from the desert centre and by geological survey, Palaeogeogr. Palaeocl., 426, 139-158, 2015.

Wang, G. X. and Cheng, G. D.: Water resource development and its influence on the environment in arid areas of China - the case of the Hei River Basin, J. Arid Environ., 43, 121-131, 1999.

Wang, N., Li, Z., Cheng, H., Li, Y., and Huang, Y.: High lake levels on Alxa Plateau during the Late Quaternary, Chinese Sci. Bull., 56, 1799-1808, 2011.

Wang, W., Zheng, W., Zhang, P., Li, Q., Kirby, E., Yuan, D., and Pang, J.: Expansion of the Tibetan Plateau during the Neogene, Nat. Commun., 8, 15887, https://doi.org/10.1038/ncomms15887, 2017.

Weltje, G. J. and Tjallingii, R.: Calibration of XRF core scanners for quantitative geochemical logging of sediment cores: theory and application, Earth Planet. Sc. Lett., 274, 423-438, 2008.

Weltje, G. J., Bloemsma, M. R., Tjallingii, R., Heslop, D., Röhl, U., and Croudace, I. W.: Prediction of geochemical composition from XRF core scanner data: a new multivariate approach including automatic selection of calibration samples and quantification of uncertainties, in: Micro-XRF Studies of Sediment Cores, Springer, Dordrecht, 507-534, 2015.

Willenbring, J. K. and von Blanckenburg, F.: Long-term stability of global erosion rates and weathering during late-Cenozoic cooling, Nature, 465, 211-214, https://doi.org/10.1038/nature09044, 2010.

Wilson, M. J.: The origin and formation of clay minerals in soils: past, present and future perspectives, Clay Miner., 34, 7-25, 1999.

Wünnemann, B.: Untersuchungen zur Paläohydrographie der Endseen in der Badain Jaran- und Tengger Wüste, Innere Mongolei, Nordwest China, Habilitation Thesis, p. 187, Freie Universität Berlin, p. 24, 1999.

Wünnemann, B. and Hartmann, K.: Morphodynamics and Paleohydrography of the Ejina Basin, Inner Mongolia, China, Z. Geomorphol., 126, 147-168, 2002.

Wünnemann, B., Hartmann, K., Altmann, N., Hambach, U., Pachur, H. J., and Zhang, H.: 22. Interglacial and glacial fingerprints from lake deposits in the Gobi Desert, NW China, in: Developments in Quaternary Sciences, Elsevier, 323-347, 2007a.

Wünnemann, B., Hartmann, K., Janssen, M., and Hucai, C. Z.: Responses of Chinese desert lakes to climate instability during the past 45,000 years, in: Developments in Quaternary Sciences, Vol. 9, Late Quaternary Climate Change and Human Adaptation in Arid China, edited by: Madsen, D. B., Chen, F., and Gao, X., 11-23, https://doi.org/10.1016/S1571-0866(07)09003-3, $2007 \mathrm{~b}$.

Yan, D.: Interplay between Lake and Catchment Processes in Kuhai Lake Basin, NE Tibetan Plateau, China during Late Holocene, Dissertation, Freie Universität Berlin, Department of Earth Sciences, 151 pp., 2017. 
Yang, X., Ma, N., Dong, J., Zhu, B., Xu, B., Ma, Z., and Liu, J.: Recharge to the interdune lakes and Holocene climatic changes in the Badain Jaran Desert, western China, Quaternary Res., 73, 10-19, 2010.

Yang, X., Scuderi, L., Paillou, P., Liu, Z., Li, H., and Ren, X.: Quaternary environmental changes in the drylands of China - a critical review, Quaternary Sci. Rev., 30, 3219-3233, 2011.

Yang, X., Li, H., and Conacher, A.: Large-scale controls on the development of sand seas in northern China, Quatern. Int., 250, 74-83, 2012.

Yao, T., Masson-Delmotte, V., Gao, J., Yu, W., Yang, X., Risi, C., Sturm, C.. Werner, M., Zhao, H., He, Y., Ren, W., Tian, L., Shi, C., and Hou, S.: A review of climatic controls on $\delta^{18} \mathrm{O}$ in precipitation over the Tibetan Plateau: Observations and simulations, Rev. Geophys., 51, 525-548, https://doi.org/10.1002/rog.20023, 2013.
Yu, K., Hartmann, K., Nottebaum, V., Stauch, G., Lu, H., Zeeden, C., Yi, S., Wünnemann, B., and Lehmkuhl, F.: Discriminating sediment archives and sedimentary processes in the arid endorheic Ejina Basin, NW China using a robust geochemical approach, J. Asian Earth Sci., 119, 128-144, 2016.

Zhang, H. C., Ming, Q. Z., Lei, G. L., Zhang, W. X., Fan, H. F., Chang, F. Q., Wünnemann, B., and Hartmann, K.: Dilemma of dating on lacustrine deposits in a hyperarid inland basin of NW China, Radiocarbon, 48, 219-226, 2006.

Zheng, D., Wang, W., Wan, J., Yuan, D., Liu, C., Zheng, W., Zhang, H., Pang, J., and Zhang, P.: Progressive northward growth of the northern Qilian Shan-Hexi Corridor (northeastern Tibet) during the Cenozoic, Lithosphere, 9, 408-416, 2017.

Zhisheng, A., Clemens, S. C., Shen, J., Qiang, X., Jin, Z., Sun, Y., and Lu, F.: Glacial-Interglacial Indian Summer Monsoon Dynamics, Science, 333, 719-723, https://doi.org/10.1126/science.1203752, 2011.

Zhu, B., Yu, J., Rioual, P., Gao, Y., Zhang, Y., and Min, L.: Geomorphoclimatic characteristics and landform information in the Ejina Basin, Northwest China, Environ. Earth Sci., 73, 75477560, 2015. 